Discussion Paper No. 10-008

Does Immigration Weaken Natives' Support for the Welfare State? Evidence from Germany

Holger Stichnoth

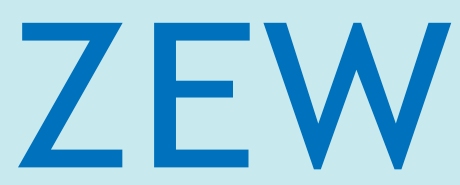

Zentrum für Europäische Wirtschaftsforschung $\mathrm{GmbH}$

Centre for European

Economic Research 
Discussion Paper No. 10-008

\title{
Does Immigration Weaken Natives' Support for the Welfare State? Evidence from Germany
}

\author{
Holger Stichnoth
}

Download this ZEW Discussion Paper from our ftp server:

ftp://ftp.zew.de/pub/zew-docs/dp/dp10008.pdf

Die Discussion Papers dienen einer möglichst schnellen Verbreitung von neueren Forschungsarbeiten des ZEW. Die Beiträge liegen in alleiniger Verantwortung der Autoren und stellen nicht notwendigerweise die Meinung des ZEW dar.

Discussion Papers are intended to make results of ZEW research promptly available to other economists in order to encourage discussion and suggestions for revisions. The authors are solely responsible for the contents which do not necessarily represent the opinion of the ZEW. 


\section{Non-technical summary}

Using data from the 1997 and 2002 waves of the German Socio-Economic Panel and from official statistics, the present paper studies whether natives are less supportive of state help for the unemployed in regions where the share of foreigners among the unemployed is high. The effect of immigration or ethnic diversity in general on the political support for the welfare state has received increasing attention in the last decade, both in academia and in the political debate. Some authors have argued that a certain social cohesion is not only the result of, but also a necessary condition for social policy and redistribution, and that ethnic diversity weakens this social cohesion. Previous empirical studies have given mixed results, however.

Unlike these previous studies, I use individual-level panel data, which allows a more convincing identification of a causal effect. Also, the effect of immigration on support for redistribution has not been studied for Germany-Europe's largest country of immigration in terms of absolute numbers - before. Finally, similar to the influential study by Luttmer (2001), I am able to relate the support for a particular aspect of the welfare state (help for the unemployed) not just to the overall share of foreigners in the population, but also to their share among the unemployed.

The main result is that there is indeed evidence that German natives' support for the unemployed is negatively affected by the regional share of foreigners among the unemployed. This still holds when individual characteristics are controlled for, and also when only the within variation is exploited, although in the latter case the estimates are not always statistically significant at conventional levels. Concerning practical significance, I find that a one standard deviation increase in the regional share of foreigners among the unemployed reduces natives' support for helping the unemployed by about two percent of the standard deviation. This effect is rather small compared to other variables such as income, self-employment, or East German origin. 


\section{Das Wichtigste in Kürze (German summary)}

Der Einfluss der Einwanderung auf die politische Unterstützung für den Sozialstaat ist in den vergangenen Jahren verstärkt zum Gegenstand der wissenschaftlichen und politischen Diskussion geworden. Eine zentrale These lautet, dass ein gewisser sozialer Zusammenhalt nicht nur Folge, sondern auch Voraussetzung staatlicher Sozialpolitik und Umverteilung ist, und dass eine zunehmende ethnische Vielfalt diesen sozialen Zusammenhalt möglicherweise schwächt. Die bisherigen empirischen Untersuchungen zu dieser These kommen allerdings zu keinen eindeutigen Ergebnissen. Für Deutschland wurde der Einfluss der Einwanderung auf die Umverteilungsbereitschaft der Bevölkerung überhaupt noch noch nicht untersucht.

Die vorliegende Studie füllt diese Lücke. Sie untersucht, inwieweit die Einstellungen deutscher Staatsangehöriger gegenüber der staatlichen Unterstützung von Arbeitslosen vom regionalen Ausländeranteil unter den Arbeitslosen beeinflusst werden. Datenbasis sind zwei Wellen des Sozio-ökonomischen Panels, die für die Zwecke der Untersuchung mit Daten der amtlichen Statistik verknüpft wurden. Hierbei wird nicht der Ausländeranteil in der Bevölkerung, sondern der für die hier untersuchte Fragestellung relevantere Anteil der Ausländer unter den Arbeitslosen berücksichtigt. Eine weitere, methodische Verbesserung gegenüber bisherigen Studien ist die Verwendung von Paneldaten auf individueller Ebene. Mit diesen Daten lässt sich ein kausaler Zusammenhang zwischen der Einwanderung und der Umverteilungsbereitschaft unter schwächeren Annahmen identifizieren.

Das zentrale Ergebnis der Studie lautet, dass ein negativer Zusammenhang zwischen dem regionalen Ausländeranteil unter den Arbeitslosen und der Zustimmung von Nichteinwanderern zu staatlicher Unterstützung für die Arbeitslosen besteht. Dieser negative Zusammenhang ist robust. Er zeigt sich auch dann, wenn andere individuelle und regionale Einflussgrößen, die die Umverteilungspräferenzen der Bevölkerung beeinflussen, kontrolliert werden. In Schätzungen, in denen der Einfluss von über die Zeit konstanten unbeobachteten Faktoren ausgeschaltet wird, ist der negative Zusammenhang allerdings nicht immer statistisch signifikant. Zudem erscheint der Einfluss der Ausländeranteils auf die Einstellungen der Nichteinwanderer grundsätzlich eher schwach. Andere Determinanten, wie etwa das Einkommen, eine Tätigkeit als Selbständiger oder eine Herkunft aus Ostdeutschland, haben einen deutlich stärkeren Einfluss auf die Einstellung gegenüber der staatlichen Unterstützung für die Arbeitslosen. 


\title{
Does Immigration Weaken Natives' Support for the Welfare State? Evidence from Germany
}

\author{
Holger Stichnoth \\ ZEW Mannheim and Paris School of Economics*
}

January 19, 2010

\begin{abstract}
Using data from the 1997 and 2002 waves of the German Socio-Economic Panel and from official statistics, I study whether natives are less supportive of state help for the unemployed in regions where the share of foreigners among the unemployed is high. Unlike previous studies, I use individual-level panel data, which allows a more convincing identification of a causal effect. I find that the negative bivariate association is mainly driven by observed individual differences such as East German origin or income. While there remains some evidence of a negative association even after adjusting for individual differences (including time-invariant unobserved differences), the association is weak compared to the association with other variables such as income, self-employment, or East German origin.
\end{abstract}

Keywords: redistribution, social security, welfare state, immigration, ethnic diversity, Germany, cluster-robust standard errors, two-way clustering

JEL codes: H53, H55, I38, J15, J61

*ZEW Mannheim, Postfach 103443, 68034 Mannheim, Germany. E-Mail: stichnoth@zew.de. I would like to thank Jürgen Schupp for helpful comments on an earlier version of the paper. 


\section{Introduction}

There is a large literature on the costs and benefits of immigration within a given system of social security; interest in whether immigration may change this system of social security in turn. For instance, Alesina et al. (2001) and Alesina and Glaeser (2004) argue that one reason why the U.S. does not have a European-style welfare state is that the ethnic diversity of the population is greater in the U.S. than in Europe. Likewise, in the debate about a reform of the system of social security, some people have argued that what may work in Denmark or other Nordic countries may not work in France or Germany where the population is more heterogeneous. The idea behind this claim is that a certain social cohesion is not only the result of, but also a necessary condition for social policy and redistribution, and that ethnic diversity weakens this social cohesion.

In this paper I study attitudes towards a particular aspect of the welfare state: help for the unemployed. I test the hypothesis that the higher the share of foreigners among the unemployed, the less natives will be in favour of state responsibility for helping the unemployed. The data are from two waves of the German Socio-Economic Panel, merged with information from official statistics on the registered unemployed.

Earlier studies have given mixed results. Using data from the General Social Survey for the years 1972 to 1993, Luttmer (2001) shows that in the U.S. people are more likely to express support for welfare spending if they live in a neighborhood where the share of people of their own race among welfare recipients is high. This is true whatever the economic situation of the respondents, even among wealthy people who have only a very small risk of being welfare recipients themselves. On the other hand, Alesina et al. (2001), who also use data from the General Social Survey, find that support among whites is not significantly associated with the share of blacks in the population of the respondent's state. Soroka et al. (2004) find for Canada that "the link [between regional ethnic diversity and support for social programs] is weak at best" (p. 50); "moving from $100 \%$ majority to $50 \%$ majority leads to a decrease in aggregate support for unemployment and welfare of about .0025\%" (p. 51). Similarly, Senik, Stichnoth, and Van der Straeten (2009), who use data from the European Social Survey, find that for Europe as a whole there is only weak evidence of a negative association between the perceived presence of immigrants and natives' support for the welfare state. However, this weak average relationship masks considerable heterogeneity across countries, and between individuals with different attitudes towards immigrants.

The main contribution of the present paper is the use of individual-level panel data, which allows identification of a causal effect under weaker assumptions. Also, the effect 
of immigration on support for redistribution has not been studied for Germany - Europe's largest country of immigration in terms of absolute numbers - before. Finally, similar to Luttmer, I am able to relate support for a particular aspect of the welfare state (help for the unemployed) not just to the overall share of foreigners in the population, but also to their share among the unemployed.

Support for the welfare state is measured by two questions from the 1997 and 2002 waves of the German Socio-Economic Panel (GSOEP). The questions ask about the extent to which the state should be responsible for the financial security of the unemployed and for job creation measures. (These are the same variables used by Alesina and Fuchs-Schündeln (2007) in their study on East-West differences in the support for redistribution.) I merge these data with official statistics on the share of foreigners among the (registered) unemployed at the level of federal states, regional planning units, and counties. There is considerable variation in this share: in the state of Brandenburg in 1997, only $1 \%$ of the unemployed were foreigners; in Baden-Wuerttemberg (where overall unemployment is much lower), the share was almost $24 \%$.

Different mean comparisons and bivariate regressions show that there is indeed a negative relationship between the regional share of foreigners among the unemployed and natives' solidarity with the unemployed. However, individuals self-select into regions, and the regional share of foreigners among the unemployed is therefore most likely endogenous. In particular, people of East German origin tend to be more supportive of the welfare state, and tend to live in regions with a low share of foreigners among the unemployed; other important common influences are income and own unemployment status. As in the previous studies, I attempt to control for such common influences by using multiple regression. Moreover, the use of individual-level panel data also allows me to eliminate all inconsistencies resulting from time-invariant unobserved factors.

The main result is that there is indeed evidence that German natives' support for the unemployed is negatively affected by the regional share of foreigners among the unemployed. This still holds when individual characteristics are controlled for, and also when only the within variation is exploited, although in the latter case the estimates are not always statistically significant at conventional levels. Concerning practical significance, I find that a one standard deviation increase in the regional share of foreigners among the unemployed reduces natives' support for helping the unemployed by about two percent of the standard deviation. This effect is rather small compared to other variables such as income, self-employment, or East German origin.

The rest of the paper is structured as follows. Section 2 motivates the empirical specification by reviewing theoretical arguments and empirical studies on individual attitudes 
towards the welfare state. Section 3 presents the data; in section 4 I begin exploring the data with simple mean comparisons. Section 5 then discusses issues of identification and of statistical inference. Section 6 gives the main results. In section 7, a number of tests are done to explore the robustness of the results. Section 8 concludes.

\section{Theoretical considerations}

In this section I motivate the empirical specification, and in particular the choice of control variables, by briefly reviewing theoretical arguments and previous empirical findings on the determinants of the support for redistribution.

\section{$2.1 \quad$ Self-Interest}

There is little doubt that people's support for redistribution is partly motivated by material self-interest and that, other things equal, people who expect to benefit materially from redistribution tend to support it. The empirical studies cited below all confirm that support for redistribution tends to be higher among people with low income.

But these studies also show that not everybody even in the lowest income decile favours more redistribution; moreover, evidence on actual redistribution shows that countries with a more inegalitarian distribution of income do not necessarily redistribute more.

These findings need not be inconsistent with material self-interest. One explanation may be that today's poor expect to be less poor and thus expect to be among the net payers tomorrow (Bénabou and Ok 2001). Consistent with this hypothesis, Ravallion and Lokshin (2000) and Alesina and La Ferrara (2005b) find that, holding current income constant, people whose income has risen in the recent past or who expect to climb the social ladder tend to be less supportive of redistribution. ${ }^{1}$

There are at least two other reasons why, to borrow Roemer (1998)'s expression, "the poor do not expropriate the rich" even in democracies, although the income of the median voter is less than the mean income. First, not even in democracies the actual amount of redistribution is a function only of the demand for it. Especially in representative democracies the outcome of the political process will depend, among other things, on the activity of interest groups. But if the median income is below the mean income, the "rich" are fewer in numbers than the "poor" and will therefore find it easier to organize and to resist attempts to distribute income away from them (this argument goes

\footnotetext{
${ }^{1}$ Likewise, even today's net payers may support state-organized redistribution as a form of insurance against downward social mobility (e.g., Buchanan and Tullock 1962; Brennan 1973; Varian 1980).
} 
back to Olson (1965)'s classic study about the logic of collective action). Moreover, as Roemer (1998) points out, people vote not only on redistribution but on a bundle of policies. Lee and Roemer (2006) and Roemer and van der Straeten (2005, 2006) show how anti-immigrant feelings - in combination with a voting system in which parties offer a policy-bundle combining economic and non-economic issues - has reduced support for the pro-redistribution party in elections in the United States, France, and Denmark.

Second, people likely take into account the distortions caused by taxation that shrink the pie that could be shared. Piketty $(1995,1996 a, b, 2003)$ finds that people who believe that effort (as opposed to external circumstances) is important for economic success tend to be less supportive of redistribution, arguably because the greater the importance of effort in production, the greater the distortions caused by taxation.

\section{$2.2 \quad$ Inter-dependent Preferences}

As Fong (2001) argues, the negative correlation between the belief in the role of effort and the support for redistribution can also stem from concerns about fairness: if people believe that the just reward is proportional to one's own effort and should be independent of circumstances for which the individual is not responsible, then their support for redistribution will be lower the greater their belief that one's economic position depends on one's own effort.

The general idea is that the support for redistribution reflects not only self-interest but also social preferences: most people care not only about their own absolute income, but also about the income, consumption, or utility of other people (Hochman and Rodgers 1969), about the income distribution as a whole (Thurow 1971), or about the way the distribution of income, consumption, or utility is arrived at. In the presence of certain inter-dependent preferences, redistribution may be Pareto-improving and even net payers may support it. ${ }^{2}$ Note that this support may not (fully) translate into actual private redistribution because of a free-rider problem; this is one argument for compulsory redistribution by the state.

\subsection{Social Distance}

There is much evidence, both from observational and from experimental studies, that altruistic behaviour depends on the situation and on the market and non-market char-

\footnotetext{
${ }^{2}$ Voluntary redistribution may also arise from self-interest, as Brennan (1973) points out. It may well be that the net payers support redistribution not out of altruism but as a form of protection against crime or civil unrest.
} 
acteristics of those involved. ${ }^{3}$ As Bowles and Gintis (2000, 45) put it, "reciprocity is more salient, the less is the perceived social distance among the participants. ... Economic inequality - particularly when overlaid with racial, ethnic, language, and other differences - increases the social distance that then undermines the motivational basis for reaching out to those in need."

The idea that social distance affects the support for redistribution has been formalized by Corneo and Grüner (2000) and tested by Corneo and Grüner (2000, 2002) and by Corneo (2003). Using the difference in occupational prestige as a proxy for social distance, they show that the greater the difference in average occupational prestige between one's own and the income class just below, the lower the support for redistribution. By contrast, the greater the social distance to the income class just above one's own, the greater the support for redistribution. In their empirical studies an important part of the crossregional or cross-country variation in the support for redistribution remains unexplained, however.

As already noted, the hypothesis of the present article is that this unexplained regional variation in the support for redistribution partly results from the variation in the share of immigrants among the beneficiaries of redistribution. The assumptions are that (A1) support for redistribution is motivated both by self-interest and by altruism; (A2) altruism is weaker the greater the perceived social distance between people, and (A3) other things equal, the perceived social distance is greater between German nationals and immigrants than within either category. ${ }^{4}$

Together, assumptions (A2) and (A3) imply that, other things equal, a German native will feel less altruistic towards an immigrant than towards another German native. Adding assumption (A1), the prediction is that other things equal, natives will be less supportive of redistribution the higher the perceived share of immigrants among the perceived beneficiaries of redistribution. The other things that have to be held equal are (1) material self-interest of the respondent; (2) attributes of the beneficiaries of redistribution other than their country of origin which may affect the respondent's support for redistribution. As in other observational studies, the present article attempts to hold these other things equal by including control variables into a parametric model. Admittedly, this approach only rarely leads to estimates of causal effects that are convincing by the standards of modern microeconometrics. Recently, the literature has therefore complemented these

\footnotetext{
${ }^{3}$ This literature has been surveyed by Miller (1992), Alesina and La Ferrara (2005a), and Stichnoth and Van der Straeten (2009).

${ }^{4}$ Models based on very similar assumptions have been formalized by Lind (2007) and by Senik et al. (2009). Technically, these models posit that in an inter-dependent utility function, the weight that person A attaches to person B's income or utility decreases the greater the social distance between the two persons. Usually, only two groups are considered, such as immigrants and natives.
} 
observational studies by experimental evidence (see the survey by Stichnoth and Van der Straeten 2009). In these experiments, assignment to treatment and control groups is random, and the characteristics of the respondents are subject to experimental control (for instance, the proposer in a trust game is told only the ethnic identity of the receiver). These experimental studies are therefore certainly the gold standard in terms of internal validity, at the well-known cost in terms of external validity.

As far as observational studies on the effect of ethnic diversity on the support for redistribution go, the present one is the first to use individual-level panel data, which allows identification of a causal effect under weaker assumptions than in the previous studies by Luttmer (2001), Alesina et al. (2001), Soroka et al. (2004), and Senik et al. (2009), which all use cross-sectional data.

\section{Data}

I merge data from the German Socio-Economic Panel (GSOEP) with data from official statistics on the share of foreigners among the registered unemployed at three different regional levels.

The GSOEP, which started in 1984, is a longitudinal survey of private households. ${ }^{5}$ I use the waves of 1997 and 2002, in which social security was a special topic. I restrict the sample to respondents with German nationality, which leaves me with 33203 person-year observations. Of these, 2833 people participated in the 1997 wave only; 8399 people participated in both waves, and 13572 people took part in the 2002 wave only. The increase in sample size between 1997 and 2002 is due to the "Supplementary Sample E" (1998), the "Innovation Sample F" (2000), and the "High-income Sample G" (2002).

The GSOEP contains regional identifiers at three different regional levels: counties, regional planning units, and federal states. For reasons of data security, the analysis with the identifiers at the levels of counties and regional planning units was done on-site at DIW Berlin. I merged the GSOEP with regional information, in particular the share of foreigners among the unemployed, that I obtained from the 1999 and 2004 editions of the CD-ROM "Indikatoren und Karten zur Raumentwicklung," (Indicators and Maps for Regional Development) published by the Bundesamt für Bauwesen und Raumordnung (Federal Office for Building and Regional Planning). ${ }^{6}$

\footnotetext{
${ }^{5}$ The data are available from the German Socio-Economic Panel Study (GSOEP) at the German Institute for Economic Research (DIW) in Berlin. See Wagner et al. (2007) for a detailed description of the GSOEP.

${ }^{6}$ Www. bbr. bund.de
} 


\subsection{Dependent variable: attitudes towards state responsibility for the unemployed}

In 1997 and 2002, participants in the GSOEP were asked whether they wanted the state or private forces to be responsible for helping the unemployed. The question ran: "At present a multitude of social services are provided not only by the state but also by private free-market enterprises, organizations, associations, or private citizens. What is your opinion on this? Who should be responsible for the following areas: only the state, mostly the state, state and private forces, mostly private forces, or only private forces?" Eleven items follow, of which I use two: state responsibility for "financial security in case of unemployment" and for "job creation measures".7

As figures 1 and 2 (both reported in the appendix) show, most respondents are in favour of some state responsibility for helping the unemployed. Support is higher for financial security than for job creation measures.

These dependent variables are admittedly not ideal. The first problem is that I would ideally like to measure natives' altruism towards the unemployed, with the goal of testing whether this altruism is lower the higher the share of immigrants among the unemployed. However, while the dependent variables are certainly consistent with such an interpretation and test, one cannot rule out an alternative interpretation, namely that natives' support for state responsibility for the unemployment is affected by the share of immigrants among the unemployed because natives take a high share as an indication that they themselves run a low risk of being unemployed themselves.

The second issue is that the two questions ask about the unemployed in general; as a result, one cannot tell whether the respondents think about unemployment benefits or unemployed assistance when they answer the question about the financial security of the unemployed. ${ }^{8}$ One may worry that respondents may interpret the two dependent variables as asking about whether unemployment insurance should be run by the state

\footnotetext{
${ }^{7}$ The nine other items are: "financial security of families", "financial security in case of illness", "financial security for old age", "financial security for persons needing care", "caring for pre-schoolers", "caring for school children", "care and help for the sick", "care and help for the aged", and "care and help for persons needing care."

${ }^{8}$ In Germany, unemployment benefits are called Arbeitslosengeld; these are the benefits paid by the system of unemployment insurance. (However, even here the benefits are financed not only out of contributions, but also out of general tax revenues). The second group are the unemployed who receive unemployment assistance (Arbeitslosenhilfe), financed out of general taxes. Recipients of unemployment assistance are mainly those people among the unemployed who were no longer entitled to receive unemployment benefits. This was the system that was in place during the period of my study. More recently, unemployment assistance has become much less generous and is now called Arbeitslosengeld II. The former Arbeitslosengeld has been renamed Arbeitslosengeld I, and the number of months during which it can be received was considerably reduced.
} 
or by private companies.

A first argument in defence of the variables is that of the two dependent variables, only one (financial security) is concerned by this problem. "Job creation measures" have no connotation with an insurance system. Accordingly, more people are in favour of private forces when they are asked about job creation measures (cf. figure 2 in the appendix).

Nevertheless, for "financial security" the issue definitely needs discussion. It is certainly true that there are good reasons (spreading the risk over as many people as possible; adverse selection) why insurance against unemployed is provided by the state and not by private companies. In fact, to my knowledge the possibility of a private insurance against unemployment has never been evoked in the German debate; the debate is always about questions such as the duration and amount of benefits, and about the conditions for receiving these benefits (e.g., the intensity of job search efforts). However, precisely because it is almost universally recognized that private companies have no role in unemployment insurance, I propose the interpretation that the respondents take the question to be mainly as being about unemployment assistance and/or the generosity of unemployment insurance (e.g., the replacement ratio). After all, if the question were interpreted as being only about who should provide unemployment insurance, then one would expect that almost everybody answers "only the state". What we observe, however, is a distribution that is roughly symmetric around the modal category "mostly the state" (if one discards the two lowest categories). So the interpretation that I propose is that the question is seen not so much as a choice between the state and private insurance companies, but as between the state and private forces in the sense that the unemployed should be responsible for themselves. This interpretation becomes clearer in the original, German version of the questionnaire. The question asks whether "der einzelne Bürger" should be responsible, which means individual responsibility. The expression "private citizens" in the English version of the questionnaire is misleading because it could also mean that other people should be responsible for helping the unemployed. (Note that this English version is only provided to the scientific community; respondents receive the German version of the questionnaire.)

However, there are at least two counterarguments. First, the wording of the question asks explicitly about who should be responsible, and does not mention generosity. Also, as noted, the low percentage of people in the two lowest categories is worrysome. If the question were interpreted as being only about generosity, then it is to be expected that some people would show themselves as being very ungenerous towards the unemployed: people who think that everybody can find a job if he or she really wants to etc. The low number of respondents in these categories therefore does suggest that at least some people 
take the question as being about the state versus private insurance companies. After all, the question asks not only about "der einzelne Bürger" (individual responsibility), but also about "marktwirtschaftliche Unternehmen, Organisationen, Verbände" (private companies, organizations, associations).

In conclusion, then, the dependent variables are not without their problems, but do seem like a reasonable compromise, bearing in mind that there are no better alternatives in the GSOEP. The fact that Alesina and Fuchs-Schündeln (2007) use the same question (in fact, all eleven items, not just the two that ask about the unemployed) for a very similar purpose lends further support to their use in the present study.

\subsection{Regressor of interest: regional variation in the share of for- eigners among the unemployed}

The regressor of interest is the share of foreigners among the registered unemployed in the respondent's region. This variable is available on a yearly basis from official statistics for three regional levels: the 16 federal states, 97 regional planning units, and 437 counties in Germany.

That I use the share of foreigners among the unemployed and not the share of immigrants (perhaps even including the second generation) is dictated by data availability: official statistics report only the share of foreigners among the unemployed and not the share of immigrants. Given that I therefore have to make do with nationality when measuring the share of the out-group among the unemployed, I choose to also distinguish respondents in the GSOEP by nationality. (The results change little when country of birth is used instead.)

As table 2 (which pools the data for 1997 and 2002) shows, the share of foreigners among the unemployed is higher than their share in the population and exhibits considerable regional variation. This regional variation is shown graphically in figure 3 , which shows the unemployment rate, the share of foreigners in the population and among the unemployed for the sixteen federal states. ${ }^{9}$ In the Eastern state of Brandenburg in 1997, $1 \%$ of the registered unemployed were foreigners; in Baden-Wuerttemberg in the same year, their share was $23.9 \%$. At the two more disaggregated levels of regions and counties, the variation is of course even greater.

The empirical strategy, described in section 5 below, will consist in using only the variation within individuals between 1997 and 2002. The cross-sectional variation between

\footnotetext{
${ }^{9}$ Rheinland-Pfalz and Saarland have been grouped together since these two states form a single category in the GSOEP.
} 
individuals is considered contaminated by unobserved individual characteristics, which are assumed to be time-invariant. After the within transformation, these unobserved time-invariant individual characteristics will be eliminated from the estimating equation. Throwing away variation will reduce the precision of the estimates. It is therefore instructive to decompose the overall variation into variation within and variation between individuals. The precision of the within-estimator will depend on how much variation is left after discarding the variation between individuals.

The total variation of a variable $x_{i t}$ around its mean $\bar{x}$ can be decomposed as

$$
\begin{aligned}
\sum_{i=1}^{N} \sum_{t=1}^{T}\left(x_{i t}-\bar{x}\right)^{2} & =\sum_{i=1}^{N} \sum_{t=1}^{T}\left[\left(x_{i t}-\bar{x}_{i}\right)+\left(\bar{x}_{i}-\bar{x}\right)\right]^{2} \\
& =\sum_{i=1}^{N} \sum_{t=1}^{T}\left(x_{i t}-\bar{x}_{i}\right)^{2}+\sum_{i=1}^{N} \sum_{t=1}^{T}\left(\bar{x}_{i}-\bar{x}\right)^{2}
\end{aligned}
$$

where $\bar{x}_{i}$ is the mean of $x_{i t}$ for individual $i$ (see, e.g, Cameron and Trivedi 2005, 709).

Table 4 shows that using only within variation comes at a large cost in terms of variation: only between 1.2 percent (federal states) and 4.5 percent (counties) of the overall variation is within variation.

Part of this low within variation can be explained by the unbalanced nature of the panel. As noted above, only 8399 people have valid information on the share of foreigners among the unemployed in both waves. This means that only $(2 * 8399) / 33203 \approx .51$ of the sample can be used for the within estimator. When only the observations from the balanced panel are used, the share of within variation is almost twice as high (see table 5). However, the share is still at most 9 percent; this low figure reflects the high persistence of the share of the foreigners among the unemployed, and the rather low geographical mobility in Germany, compared to, say, the U.S.

\subsection{Control variables}

The GSOEP allows to control for a number of variables that influence both a person's support for the welfare state and his place of residence and hence the regional share of foreigners among the unemployed.

I control for the respondent's gender, labour force status, income, education, age, marital status, and household composition. Socialization in East Germany is proxied by a dummy variable that indicates whether the respondent lived in West or East Germany in 1989. Table 3 in the appendix reports summary statistics for the individual-level control 
variables.

In addition to these individual characteristics, in some specifications I control for the area's unemployment rate and for the share of foreigners in the population (as opposed to their share among the registered unemployed). Finally, I include a year dummy in the model to allow the overall support for redistribution to differ between 1997 and 2002.

Table 6 (in the appendix) shows that mean values of these control variables differ between respondents who support state responsibility for the unemployed and respondents who favour private responsibility. People who are for state responsibility tend to be disproportionately East German (defined either by residence in 1989 or by current residence). Alesina and Fuchs-Schündeln (2007) have shown that this holds true even controlling for other factors. Moreover, and consistent with theories that point to material self-interest as a determinant of support for the welfare state, the table shows that people who favour state responsibility for the unemployed are twice as likely to be unemployed themselves; that they tend to have a lower household income, and that they are less likely to have a secondary degree (Abitur) or a college degree. ${ }^{10}$ By contrast, the table shows that there is little difference with respect to sex or marital status.

\section{Mean comparisons}

I begin the analysis by exploring the bivariate association between the share of foreigners among the unemployed and natives' support for redistribution. Table 7 shows that German nationals who support state responsibility for the financial security of the unemployed tend to live in regions with a lower share of foreigners among the unemployed. This is true for all three regions: federal states, regional planning units, and counties. As the last column of the table shows, the differences are highly statistically significant. The table shows these statistics only for the dependent variable "financial security of the unemployed"; similar results are obtained for the other dependent variable "job creation". In table 8 the bivariate relationship between the share of foreigners among the unemployed and the support for redistribution is shown from a slightly different angle. The table shows that mean support for helping the unemployed is lower in regions where the share of foreigners among the unemployed is above the median. This holds for all three regions and for all three variables used to measure the support for redistribution. (Each panel of

\footnotetext{
${ }^{10}$ These mean differences are highly statistically significant. The last column of the table shows p-values from t-tests for the statistical significance of the difference of the means between the two categories. For each variable, the assumption of equal variances has been tested using Bartlett's $\chi^{2}$. If the assumption is rejected, the t-test is conducted with an adjustment for unequal variances.
} 
the table corresponds to a region; within each panel, each line corresponds to a different dependent variable).

However, given that people self-select into regions, there are likely to be third factors that influence both the support of redistribution and the share of foreigners among the unemployed in the respondent's region. It has already been pointed out above (and documented in table 6) that people who support state responsibility for the unemployed tend to be poorer, disproportionately often from East Germany, and that they have a higher probability of being unemployed themselves. Table 9 shows that some of these variables also predict whether a respondent lives in a county with a high or low share of foreigners among the unemployed. ${ }^{11}$ For instance, among people who live in counties with a low share of foreigners among the unemployed, East Germans (defined by residence in 1989 or by current residence) are overrepresented. Moreover, people in counties with a low share tend to have lower household income and are more likely to be unemployed. As noted, all these factors are also positively correlated with the support for the state helping the unemployed, and will therefore at least partly drive the negative bivariate relationship between the share of foreigners among the unemployed and support for helping the unemployed.

\section{Specification}

So far, I have documented that there is a negative association between the share of immigrants among the unemployed and natives' support for state help for the unemployed. However, there is also evidence that this negative bivariate association may be driven by third variables such as material self-interest (income, own unemployment) or by a socialization in East Germany. In this section I therefore attempt to control for third factors in a multivariate model.

The basic specification derives from the theoretical considerations of section 2 . The support of native $i$ in area $k$ in year $t$ is modelled as

$$
\text { Support }_{i k t}=\mathbf{x}_{\mathbf{i k t}}^{\prime} \beta+\alpha_{i}+\varepsilon_{i k t}
$$

Support $_{i k t}$ measures support for state help for the unemployed. The regressor of interest in $\mathbf{x}_{\mathbf{i k t}}$ is ShareForeign $k$, the share of foreigners among the registered unemployed in area $k$. In addition, $\mathbf{x}_{\mathbf{i k t}}$ contains a number of control variables. As noted in section 3 ,

\footnotetext{
${ }^{11}$ The table shows these associations at the level of counties; results are similar at the levels of regions and federal states.
} 
I control both for individual and for area-level characteristics. Depending on the model, the area subscript $k$ indexes counties, regional planning units, or federal states.

Note that the slope coefficients are assumed to be fixed and identical across observations. By contrast, the intercept $\alpha_{i}$ is a random variable that captures unobserved heterogeneity between individuals.

\section{$5.1 \quad$ Identification}

I assume that the idiosyncratic error is strictly exogenous:

$$
\mathbb{E}\left(\varepsilon_{i k t} \mid \alpha_{i}, \mathbf{x}_{\mathbf{i k} \mathbf{1}}, \mathbf{x}_{\mathbf{i k 2}}\right)=0 \quad t=1,2
$$

Strict exogeneity assumes that all time-varying unobserved effects have zero mean conditional not only on current, but also on past and future values of the regressors. In other words, I assume that all unobserved variables that are correlated with the regressors are time-invariant and are therefore captured by $\alpha_{i}$.

Admittedly, the assumption of strict exogeneity is quite strong. The only defense is that is is less strong than in previous studies on the effect of ethnic diversity on the support for redistribution. These earlier studies use repeated cross-sections and therefore include both time-varying and time-invariant unobserved effects in the error term $\varepsilon_{i k t}$. Because the present study uses panel data, at least the time-invariant unobserved effects are eliminated as a source of inconsistency. Of course, it would be highly desirable to find valid external instruments for the share of foreigners among the registered unemployed in a region.

Under strict exogeneity, the conditional mean of Support $t_{i k t}$ is given by

$$
\mathbb{E}\left(\text { Support }_{i k t} \mid \mathbf{x}_{\mathbf{i k t}}\right)=\mathbb{E}\left(\alpha_{i} \mid \mathbf{x}_{\mathbf{i k t}}\right)+\mathbf{x}_{\mathbf{i k t}}^{\prime} \beta
$$

The main modelling decision concerns the relation between the regressors and the unobserved, time-invariant individual-specific effect $\alpha_{i}$. It seems likely that despite the inclusion of a standard set of control variables, there are still some unobserved time-invariant, individual-specific factors that affect both ShareForeign $n_{i k t}$ and the support for helping the unemployed. Hence, it is likely that $\mathbb{E}\left(\alpha_{i} \mid \mathbf{x}_{\mathbf{i k t}}\right) \neq 0$; under this assumption, pooled OLS or random effect estimators will be inconsistent. However, the time-invariant unobserved effect $\alpha_{i}$ can be eliminated through a within-transformation that expresses all variables as deviations from their individual means. This within estimator is consistent under the (weaker) assumption that all unobserved heterogeneity is time-invariant. 
The possibility of these transformations that eliminate $\alpha_{i}$ explains why I choose to estimate a linear model, even though the dependent variables that I use are categorical (with five answer categories). This modelling decision is popular in applied microeconometrics; it is generally believed that a linear fixed-effects model is superior to a non-linear random effects model in applications like the present one (Ferrer-i-Carbonell and Frijters (2004) make a similar case concerning studies on the determinants of life satisfaction).

\subsection{Statistical inference}

\subsubsection{Heteroskedasticity and serial correlation}

With panel data, the unobserved time-varying components in different time periods are likely to be correlated for the same individual. Moreover, the error terms are likely to be heteroskedastic. For both reasons, inference should not be based on the assumption of independent and identically distributed errors, but rather on a panel-robust estimate of the asymptotic variance matrix, which takes into account both heteroskedasticity and between-period correlation of error terms for the same individual. The panel-robust estimator is given as

$$
\hat{\mathrm{V}}_{\text {oneway }}(\hat{\beta})=\left[\sum_{i=1}^{N} \sum_{t=1}^{T} \tilde{\mathbf{w}}_{i t} \tilde{\mathbf{w}}_{i t}^{\prime}\right]^{-1} \sum_{i=1}^{N} \sum_{t=1}^{T} \sum_{s=1}^{T} \tilde{\mathbf{w}}_{i t} \tilde{\mathbf{w}}_{i s}^{\prime} \hat{u}_{i t} \hat{u}_{i s}\left[\sum_{i=1}^{N} \sum_{t=1}^{T} \tilde{\mathbf{w}}_{i t} \tilde{\mathbf{w}}_{i t}^{\prime}\right]^{-1}
$$

where $\hat{u}_{i t}$ is the residual for individual $i$ in period $t, \tilde{\mathbf{w}}_{i t}=\left(\begin{array}{ll}1 & \mathbf{x}_{1 i t}^{\prime}\end{array}\right)$ for pooled OLS and $\tilde{\mathbf{w}}_{i t}=\left(\mathbf{x}_{1 i t}-\overline{\mathbf{x}}_{i}\right)$ for the within estimator. $\mathbf{x}_{1 i k t}$ contains all time-varying regressors that appear in $\mathbf{x}_{i k t}$. (See, for instance, Arellano 1987; Cameron and Trivedi 2005).

\subsubsection{Clustering at the area-level}

The variance estimator of equation (6) allows for "one-way" clustering: it allows for correlation in the unobserved factors between the same individual in different periods, but assumes that the unobserved factors are uncorrelated across individuals. However, since I include area-level covariates, measurement error will introduce correlation in the error terms of different individuals living in the same area.

In cross-sectional data, clustering is easily dealt with by applying the expression of equation (6): the only difference is that one sums over observations for different individuals in each cluster, instead of summing over different time periods for each individual.

However, in this paper the issue is more complicated because both serial correlation and the correlation within an area should be taken into account. To accomplish this, I use the 
variance estimator that was proposed recently by Thompson (2006) and Cameron et al. (2006): they show that the variance estimator which allows for clustering at both the individual and the area level is equal to the variance estimator that allows for individuallevel clustering, plus the variance estimator that allows for area-level clustering, minus White (1980)'s heteroskedasticity-robust covariance estimator, which assumes independent errors: $:^{12}$

$$
\hat{\mathrm{V}}_{\text {twoway }}(\hat{\beta})=\hat{\mathrm{V}}_{\text {oneway,time }}+\hat{\mathrm{V}}_{\text {oneway, area }}-\hat{\mathrm{V}}_{\text {het. robust }}
$$

where the expressions for the two oneway-cluster variance estimators are given by equation (6), and where

$$
\hat{\mathrm{V}}_{\text {het. robust }}(\hat{\beta})=\left[\sum_{i=1}^{N} \sum_{t=1}^{T} \tilde{\mathbf{w}}_{i t} \tilde{\mathbf{w}}_{i t}^{\prime}\right]^{-1} \sum_{i=1}^{N} \sum_{i=1}^{T} \hat{u}_{i t}^{2} \tilde{\mathbf{w}}_{i t} \tilde{\mathbf{w}}_{i t}^{\prime}\left[\sum_{i=1}^{N} \sum_{t=1}^{T} \tilde{\mathbf{w}}_{i t} \tilde{\mathbf{w}}_{i t}^{\prime}\right]^{-1}
$$

\section{$6 \quad$ Results}

This section presents results for a number of models, which are all variants of equation (3). There are six basic combinations: two different dependent variables (financial support for the unemployed and job creation measures) and three regional levels at which the share of foreigners among the unemployed is measured (counties, regional planning units, federal states). For each of these combinations, the set of covariates is gradually built up: I begin with a bivariate model and then include a growing number of individual controls. Finally, aggregate-level controls will be added as well; these results are presented in section 7 below.

To avoid losing track given this large number of variants, I present only the estimated coefficients for the share of foreigners among the unemployed in this section; coefficient estimates for the control variables can be found in the appendix. Moreover, I show results only for the bivariate regression and then for a model with the full set of controls here; the gradual built-up of the specification is also documented in the appendix.

Table 1 shows estimated coefficients for the regressor of interest when the dependent variable is the support for financial security of the unemployed. The first two columns of the table correspond to a bivariate model; columns 3 and 4 are for a model with the full set of individual controls. Intermediate specifications, in which only subsets of the individual controls are included, are shown in tables 10, 11, 12 (random effects) and 13, 14, 15 (fixed effects) in the appendix. These tables also report estimated coefficients for

\footnotetext{
${ }^{12}$ Thompson (2006) considers the case of two-way clustering in the linear model; Cameron et al. (2006) consider the general case of multi-way clustering, in both linear and non-linear models.
} 
Table 1: Overview of results for the dependent variable 'state responsibility for the financial security for the unemployed'

\begin{tabular}{lcccc}
\hline & \multicolumn{2}{c}{ Bivariate } & \multicolumn{2}{c}{ Full controls } \\
& $\mathrm{RE}$ & $\mathrm{FE}$ & $\mathrm{RE}$ & $\mathrm{FE}$ \\
\hline County & $-.0089^{*}$ & -.0043 & $-.0018^{*}$ & -.004 \\
& $(.00054)$ & $(.0022)$ & $(.0007)$ & $(.0023)$ \\
Regional planning unit & $-.011^{*}$ & $-.008^{*}$ & $-.0018^{*}$ & -.0069 \\
& $(.00059)$ & $(.004)$ & $(.00086)$ & $(.0042)$ \\
Federal state & $-.014^{*}$ & -.0089 & $-.0023^{*}$ & -.0045 \\
& $(.00063)$ & $(.0049)$ & $(.0011)$ & $(.0054)$ \\
\hline \multicolumn{2}{c}{ Note: Asymptotic standard errors-robust to heteroskedasticity and serial correlation-are }
\end{tabular}

shown in parentheses. An asterisk denotes statistical significance at the $5 \%$ level.

the control variables.

The standard errors in the table are robust to heteroskedasticity and serial correlation. Note that I do not yet use the variance estimator that allows for two-way clustering here, because the expression for $\hat{\mathrm{V}}_{\text {oneway, area }}$ in equation (7) assumes that an individual is part of exactly one area cluster. Since some people change their area of residence, this does not hold for everybody in the sample. In subsection 7.2 below I will therefore restrict the sample to people who stay in the same area, in order to use the variance estimator of equation (7).

\subsection{Random effects}

The results for the random effects models are shown in columns 1 and 3 of table 1 , and in tables 10,11 , and 12 .

Sign and statistical significance At all three geographical levels, there is evidence of a negative bivariate relationship. The coefficient estimates are -0.0089 when the share of foreigners is measured at the county level, -0.011 when it is measured at the level of regional planning units, and -0.014 when it is measured at the level of federal states. All three estimates are highly statistically significant.

Columns (2) to (5) of tables 10, 11, and 12 show that the coefficients are reduced in absolute magnitude as further controls are added. As expected from the discussion of the bivariate associations in section 3, the biggest reductions occur once income and East German origin are added as controls. As noted, natives who live in areas with a high share of foreigners among the unemployed tend to have a lower income; at the same time, people with low income tend to support help for the unemployed, arguably out of 
material self-interest (because they have fewer own resources on which to fall back during a spell of unemployment, and a higher risk of becoming unemployed in the first place). East German residence (in 1989 or in the current periods of 1997 and 2002) is associated with a low share of foreigners among the unemployed; at the same time, the table shows that East Germans tend to be more supportive of state help for the unemployed, even controlling for material self-interest. ${ }^{13}$

However, the principal result is that the marginal effect of a change in the share of foreigners among the unemployed in a region on the support for state help for the unemployed remains negative and significantly different from zero even after these individual characteristics are controlled for.

Size of the coefficients With full individual controls, the estimated coefficients in the random-effects model are -0.0018 for counties and regions, and -0.0023 for federal states.

To put these estimates into perspective, table 2 shows that the mean share of foreigners among the unemployed is slightly above $13 \%$. Typical regions in this respect are Osnabrück with a share of $13.3 \%$ or Siegen with a share of $13.5 \%$. The standard deviation is about 9 percentage points for regional planning units. Shares of around $13 \%+9 \%=22 \%$ are observed in regions such as Düsseldorf or Franken; shares of around $13 \%-9 \%=4 \%$ are observed in the South-West of Schleswig-Holstein or Western Saxony.

A one standard deviation increase in the share of foreigners among the unemployed (e.g., the difference between Osnabrück and Düsseldorf) is thus associated with a reduction in support of around $9 \cdot(-0.0018)=-0.0162$, once observed individual characteristics are controlled for.

The dependent variable "financial support" has a mean of 3.9 and a standard deviation of 0.8. That is, a one standard deviation increase in the share of foreigners among the unemployed is associated with a reduction in support for financially helping the unemployed of about two percent of the standard deviation of the dependent variable $(0.0162 / 0.8 \approx 0.02)$. This is a very small effect when compared to the influence of variables such as East German origin or household income. As column 5 of table 11 shows, people of East German origin tend to be more supportive by 0.2 points, more than ten times the difference associated with a one standard deviation increase in the

\footnotetext{
${ }^{13}$ In this respect, the present paper is a partial replication study of Alesina and Fuchs-Schündeln (2007)'s article, and confirms their main results concerning the variables related to state help for the unemployed. The replication is only partial because Alesina and Fuchs-Schündeln use a wider set of dependent variables. By contrast, and as noted above, I focus on support for the unemployed because this is the measure of support for the welfare state that corresponds directly to the regressor of interest, namely the share of foreigners among the unemployed.
} 
share of foreigners among the unemployed.

Results for control variables Concerning the other control variables, I find that the findings from the mean comparisons of section 4 survive in the multivariate regression models. In the random-effects models, people with high income or high wealth (proxied for by home ownership) tend to be less supportive of state help for the unemployed. For a given household income, support increases with household size. People who are currently unemployed themselves tend to be more supportive. The self-employed tend to be much less supportive. Even controlling for other factors, people with a secondary school degree (Abitur) tend to be less supportive. Women tend to be more supportive than men.

Evidence on the relationship between expected future income and the support for redistribution comes from two questions about people's economic concerns. Since I hold current income constant, these questions are supposed to measure people's expectations about whether they may personally benefit from the welfare state in the future; that is, the questions still proxy for material self-interest, but the self-interest is less myopic than in the case of current income. Consistent with Bénabou and Ok (2001)'s "POUM hypothesis" (probability of upward mobility), I find that people who are concerned about their own financial situation and about the economy as a whole tend to be more supportive of redistribution.

\subsection{Fixed effects}

The advantage of this article over previous studies is that I use panel data; by using only the "within" variation, I can therefore eliminate all inconsistency stemming from time-invariant omitted variables.

However, the price to pay for discarding the potentially contaminated "between" variation is that the precision of the estimates will be reduced. As shown in section 3, in the unbalanced panel only 4.8 percent of the overall variation is within variation in the present application. This low figure reflects the high persistence of the share of the foreigners among the unemployed, and the rather low geographical mobility in Germany, compared to, say, the U.S. As a result, while the data used in the present article offer an advantage in principal, the actual benefit is modest given the small within variation that are observed with only two waves. ${ }^{14}$ The low within variation shows up in the fixed

\footnotetext{
${ }^{14}$ In future work I plan to go back to the GSOEP waves of 1987, 1992, and 1997, which contain a general question on whether the state should be responsible for social security. However, compared to the variables used in the present version of this article, the general question of the three earlier waves has the drawback that it does not specifically ask about support for the unemployed. The link with the
} 
effects estimates, which are shown in columns 2 and 4 of table 1 , and in tables 13, 14, and 15 in the appendix.

The point estimates for the effect of the share of foreigners among the unemployed on German nationals' support for helping the unemployed are again negative for all three regional levels.

Concerning statistical significance, I find that the coefficients for the model with full individual controls are insignificant at conventional levels for federal states and regional planning units: the estimated coefficients are-0.0069 (SE: 0.004) and -0.0045 (SE: 0.005), respectively. At the level of counties, the estimated coefficient of -0.004 is weakly significant (SE: 0.0023). Its point estimates is almost twice as large in absolute value as for the random effects model (-0.004 versus -0.0018). However, as discussed above, even this larger coefficient is small compared to the coefficients for income or education. ${ }^{15}$

\subsection{Hausman tests}

Following Hausman (1978), I test whether the coefficient estimates on the time-varying regressors obtained using the within-estimator are significantly different from the estimated obtained with the random-effects estimator. However, the random effects estimator is not fully efficient if the error term is not iid; as a result, the simplified test statistic of the Hausman test, in which only the difference of two variance estimators enters the expression, cannot be used. Instead, one needs the more complicated expression for the variance of the difference between the estimators (see Cameron and Trivedi 2005, 718).

As a way to avoid calculating this variance of the difference, Wooldridge (2002) proposes to do a Wald test with panel-robust standard errors of $\gamma=\mathbf{0}$ in the auxiliary regression ${ }^{16}$

$$
y_{i t}-\hat{\lambda} \bar{y}_{i}=1-\hat{\lambda}+\left(\mathbf{x}_{1 i t}-\hat{\lambda} \overline{\mathbf{x}}_{1 i}\right)^{\prime} \beta_{\mathbf{1}}+\left(\mathbf{x}_{1 i t}-\overline{\mathbf{x}}_{1 i}\right)^{\prime} \gamma+\nu_{i t}
$$

share of foreigners among the unemployed is therefore weaker.

${ }^{15}$ Generally, tables 13,14 , and 15 show that in the fixed-effects models the coefficients on the control variables tend to have the same signs as in the random effects model, but due to the smaller variation, many of the coefficients are no longer statistically significant. Coefficients on time-invariant regressors such as sex or East German origin are not identified at all, of course.

${ }^{16}$ A caveat: for the case where the random-effects estimator is fully efficient, Hausman (1978) shows that this auxiliary regression is asymptotically equivalent to the original Hausman test. However, when the RE estimator is not fully efficient, as in the present application, it is not clear that the two tests coincide (Cameron and Trivedi 2005, 719). 
where $\mathbf{x}_{1 i t}$ contains only the time-varying regressors, $y_{i t}$ is short for Support $_{i t}$, and where

$$
\hat{\lambda}=1-\frac{\hat{\sigma}_{\varepsilon}}{\sqrt{\hat{\sigma}_{\varepsilon}^{2}+T \hat{\sigma}_{\alpha}^{2}}}
$$

Here, $\sigma_{\varepsilon}^{2}$ is the variance of the idiosyncratic error, and $\sigma_{\alpha}^{2}$ is the variance of the unobserved individual effects. $T$, the number of time periods, is equal to 2 .

Table 16 in the appendix shows the test statistics and p-values for a Wald test of $\gamma=\mathbf{0}$, for each of the three regional levels. Only test results for the model with full individual controls are shown; the test results for the intermediate models (with only subsets of the individual controls) give similar results. The first line in each cell shows the test statistic, the second line shows the associated p-value. An asterisk denotes statistical significance at the $5 \%$ level. As noted, the test statistic is based on panel-robust standard errors ${ }^{17}$ I find that in all but one case the test rejects the null hypothesis that time-varying parameters are the same for the random effects estimator and the within estimator.

In conclusion, then, the tests show that the random effects estimates are likely to be inconsistent. At the same time, the fixed effects estimates - which are consistent under the assumption that all unobserved heterogeneity is captured by a time-invariant interceptare rather imprecisely estimated because only a very small part of overall variation is within variation. In fact, for almost all models of tables 1, the fixed effects estimates are not significantly different from zero. Concerning practical significance, it has been shown above that the random effects estimates suggest a rather weak influence of the share of foreigners among the unemployed on German nationals' support for helping the unemployed. The same conclusion holds for the fixed-effects estimates. For the level of federal states, the model with full individual controls estimates the lower bound of the $95 \%$ confidence interval to be roughly $-0.0045-2 \cdot 0.005=-.0145$; for regional planning units, this lower bound is very similar at about $-0.0069-2 \cdot 0.004=-.0149$. For counties, the association is even weaker, with a lower bound of approximately $-0.004-2 \cdot 0.002=-.008$. As column 5 of tables 13, 14, and 15 show, even these lower bounds are small (in absolute values) compared to the influence of other variables such as education: for instance, the point estimate for the dummy Abitur (secondary school degree) is -0.17 for counties, -0.2 for regional planning units, and -0.16 for federal states.

\footnotetext{
${ }^{17}$ From a practical point of view, panel-robust inference means that Stata's built-in hausman command cannot be used. The auxiliary regression and the Wald tests have to be implemented "by hand".
} 


\section{Robustness checks}

In this section I report results for four robustness checks: I use a different dependent variable (section 7.1), restrict the sample to people who lived in the same area in 1997 and 2002 (section 7.2), and explore observed parameter heterogeneity by re-estimating the models for different geographical subsamples (section 7.3). Finally, I discuss the effects of introducing further area-level controls (section 7.4).

\subsection{A different dependent variable: job creation}

So far, all results have been obtained for the dependent variable that asks whether the state should be responsible for the financial security of the unemployed. Table 17 in the appendix shows estimation results for the same models as in table 1, but for a different dependent variable. ${ }^{18}$ The variable measures whether respondents think that the state should be responsible for job creation measures.

The basic results are unchanged: there is evidence of a negative relationship between the share of foreigners among the unemployed and German nationals' support for helping the unemployed, but the practical significance of the estimated coefficients is again small compared to other variables such as income or East German origin. In the fixed effects models, the coefficients are never significantly different from zero. Finally, table 16 shows that, as for the variable "financial security for the unemployed", Hausman tests reject the null hypothesis of equal parameters in the random effects and fixed effects models also for the variable "job creation".

\subsection{Two-way clustering}

So far, I have reported standard errors that are robust to heteroskedasticity and to serial correlation in the idiosyncratic component of the error term. However, I have not yet used the variance estimator that allows for two-way clustering, because the expression for $\hat{\mathrm{V}}_{\text {oneway, area }}$ in equation (7) assumes that an individual is part of exactly one area cluster. Since some people change their area of residence between 1997 and 2002, this does not hold for everybody in the sample.

I now restrict the sample to people who stay in the same area, in order to use the variance estimator of equation (7). There are 8074 people in the sample for which information on

\footnotetext{
${ }^{18}$ Due to space constraints, only the coefficients of main interest are reported for this dependent variable. The results for the control variables are available from the author upon request.
} 
the county of residence are available in both periods; for regional planning units and for federal states, the numbers are 5329 and 8399, respectively. 8056 (96 percent) of these live in the same federal state in 1997 and 2002; 4799 (90 percent) live in the same regional planning unit, and 5191 (64 percent) live in the same county. ${ }^{19}$

This means that the within-variation is further reduced: now all within-variation comes from changes in the share of foreigners among the unemployed in a given region. The advantage is that time-invariant characteristics of the area, which influence both the support for redistribution and the share of foreigners among the unemployed, no longer render the estimator inconsistent. Above, only time-invariant characteristics of the individuals were eliminated from the models by the within-transformation.

The disadvantage is a further loss in the precision of the estimates. In fact, the share of foreigners among the unemployed in an area is highly persistent: the correlation between the share in 1997 and the share in 2002 is 0.9962 for federal states, 0.9926 for regional planning units, and 0.8540 for counties.

Finally, people who stay in the same area are likely to be a non-random sub-sample of all people in the GSOEP, even conditional on observable differences. One cannot rule out that unobserved factors that lead people to move are correlated with the share of foreigners among the unemployed. Inference is therefore with respect to the population of "stayers" only, and not with respect to the whole population of German nationals as in the tables above.

Tables 18 and 19 show the results when the model is estimated on this sample of "stayers". The standard errors reported in the tables are now robust not only to heteroskedasticity and serial correlation, but also to contemporaneous correlation between individuals living in the same period; as noted, this correlation would arise from measurement error in the area-level variables or from unobserved area-level influences on the support for redistribution. (As expected, these standard errors are considerably larger than in table 1 , which contains both stayers and movers and which assumes that the unobserved terms are uncorrelated across individuals even within an area.) The association between the share of foreigners among the unemployed and natives' support for redistribution is again found to be negative, even controlling for a host of individual characteristics. Moreover, by restricting the sample to people who live in the same area in 1997 and 2002, omitted variables bias from unobserved characteristics of the area can also be ruled out, at least as long as these characteristics and their influence were the same in the two years. However, although the coefficients are larger in size than for the entire sample, for most

\footnotetext{
${ }^{19}$ Some of these people may have lived in other areas between 1997 and 2002; here, only the information on where the people are observed in 1997 and 2002 is used.
} 
variants of the model the association is still rather weak compared to that observed for other variables. There is one exception, however: when the share of foreigners among the unemployed is measured at the level of federal states, and support for helping the unemployed is measured by the question about financial security, the estimated coefficient is -0.053 in the fixed-effects model with full individual controls. That is, an increase in the share of foreigners among the unemployed of one standard deviation (nine percentage points) is associated with a decrease in the support for helping the unemployed of about -0.47 . This is quite sizeable compared to other main influences on the support for redistribution. For instance, a random-effects model estimated on the same sample of "stayers" shows that the self-employed tend to be less supportive by -0.21 points, whereas the support tends to be higher by 0.18 points for people who lived in the East in 1989 (the table with these results is not reported here for the sake of brevity).

\subsection{Separate models for East and West Germany}

Given these East-West differences in the support for the welfare state - already highlighted by Alesina and Fuchs-Schündeln (2007) — the model has also been estimated separately by current region and by region in 1989. Unlike in the previous robustness check, the estimation sample again includes both people who live in the same area in 1997 and 2002, and those people who are observed in two different areas. As in the main models above, the variance-covariance estimator is robust to heteroskedasticity and serial correlation, but not to clustering within areas.

Tables 20 and 21 in the appendix report the results when the model is estimated separately for people who lived in the East in 1989 and for those who lived in the West. Tables 22 and 23 distinguish by current region of residence. To save space, only the results for the dependent variable "financial security of the unemployed" are reported. These four tables reinforce the conclusion that was drawn for the main model above, namely that the regional share of foreigners among the unemployed is not a strong predictor of natives' support for helping the unemployed. Most point estimates are negative, but all are small in size and many are not significantly different from zero.

\subsection{Influence of other area-level variables}

Counties, regional planning units, and federal states that differ in the share of foreigners among the unemployed will also differ in other respects. So far, these other differences 
were part of the error term. ${ }^{20}$ However, to the extent that these unobserved area-level variables are correlated with both the share of foreigners among the unemployed and with natives' support for helping the unemployed, the OLS estimates will be biased.

Two of these area-level variables are of special interest. First, Luttmer (2001) shows that the support for welfare is lower in communities with high rates of welfare recipients. Luttmer calls this a "negative exposure effect" - the effect that "individuals decrease their support for welfare as the welfare recipiency rate in their community rises" (Luttmer 2001, 500). Luttmer argues that such "a negative relationship could arise from financial or psychological costs that respondents attribute to giving welfare to local recipients" (p. $506)$.

The equivalent in the present article is to study how the unemployment rate in an area affects the support for helping the unemployed. In all specifications so far I did already control for individual unemployment status in the current period, but the risk of being unemployed in the future will depend on regional unemployment rate. As noted, I have already partly captured this risk by controlling for individuals' subjective concerns about their own economic situation and about the economy in general. However, there may still be a case for including the regional unemployment rate as well, because it will affect the expected duration of unemployment and the stigma attached to it. As noted above, the unemployment rate and the share of foreigners among the unemployed are negatively correlated in Germany. The correlation coefficient is - .84 for federal states, -.68 for regional planning units, and -.50 for counties. The negative correlation mainly reflects that areas in East Germany tend to have both high rates of unemployment and low shares of foreigners in the population and among the unemployed. But even in West Germany the correlation is negative (except for counties, where the two variables are basically unrelated, with $r=0.05)$.

Column 1 of tables 26 - 31 in the appendix show that the regional unemployment rate tends to be positively associated with natives' support for helping the unemployed. ${ }^{21}$ That is, I do not find evidence for the "negative exposure effect" that Luttmer (2001) finds for the support for welfare spending in the U.S.

The second area-level variable that needs to be discussed is the share of foreigners in the population, as opposed to their share among the registered unemployed. The problem

\footnotetext{
${ }^{20}$ Except in section 7.2, where all time-invariant area characteristics were eliminated in the estimation. In the present subsection, by contrast, the focus is on the influence of area characteristics that do vary over time.

${ }^{21}$ To save space, results are only shown for the dependent variable that asks about the financial security of the unemployed. The same positive association is found for the other dependent variable that asks about job creation measures.
} 
here is that the two variables are highly correlated: the correlation coefficient is .98 for federal states, .97 for regional planning units, and .93 for counties.

The results that are obtained when the population share of foreigners is nevertheless added to the model can be found in column 2 of tables $26-31$ in the appendix. The results are mixed: in the random-effects models, the coefficient on the population share of foreigners is negative for counties, statistically insignificant for regional planning units, and positive for federal states. In the fixed-effects models, the same pattern is found, but the coefficients are less precisely estimated and are at best marginally significant.

Concerning the coefficient on the share of foreigners among the unemployed, the results are again mixed. In the random-effects models, the estimate is positive for counties, insignificant for regional planning units, and negative for federal states. In the fixed-effects models, the coefficient is significant only for federal states, where it is again negative. Even for federal states the coefficient suggests that the association is less strong than for other covariates such as self-employment or income.

\section{Conclusion}

Based on data from the 1997 and 2002 waves of the German Socio-Economic Panel and from official statistics, this article has studied whether natives are less supportive of state help for the unemployed in regions where the share of foreigners among the unemployed is high. Unlike in previous studies using (repeated) cross-sections, the models were estimated using individual-level panel data, which allows more convincing identification of a causal effect.

The main result is that there is indeed evidence that German natives' support for the unemployed is negatively affected by the regional share of foreigners among the unemployed. Mean comparisons show that people in areas with a high share of foreigners among the unemployed do tend to be less supportive of state help for the unemployed. However, much of this difference is driven by common influences such as income or East German origin. Once these individual characteristics are controlled for, the share of foreigners among the unemployed is still negatively associated with natives' support for the unemployed, but the association is rather weak compared to other variables such as income, self-employment, or East German origin.

Although not the main focus of this paper, two other results relating to earlier studies have been obtained. First, I find that East Germans tend to be more supportive of state help for the unemployed, even controlling for material self-interest. This confirms the 
results by Alesina and Fuchs-Schündeln (2007), who use almost the same data and similar specifications. By contrast, I did not find evidence for a "negative exposure effect," the effect that "individuals decrease their support for welfare as the welfare recipiency rate in their community rises" (Luttmer 2001, 500). In Germany, the regional unemployment rate tends to be positively associated with natives' support for helping the unemployed.

\section{References}

Alesina, A. and N. Fuchs-Schündeln (2007). Good-bye Lenin (or not?): the effect of communism on people's preferences. American Economic Review 97(4), 1507-28.

Alesina, A. and E. Glaeser (2004). Fighting Poverty in the U.S. and in Europe: A World of Difference. New York: Oxford University Press.

Alesina, A., E. Glaeser, and B. Sacerdote (2001). Why doesn't the U.S. have a Europeanstyle welfare system? Brookings Papers on Economic Activity 2, 187-278.

Alesina, A. and E. La Ferrara (2005a). Ethnic diversity and economic performance. Journal of Economic Literature 43, 762-800.

Alesina, A. and E. La Ferrara (2005b). Preferences for redistribution in the land of opportunities. Journal of Public Economics 89(5-6), 897-931.

Arellano, M. (1987). Computing robust standard errors for within-group estimators. Oxford Bulletin of Economics and Statistics 49, 431-434.

Bénabou, R. and E. A. Ok (2001). Social mobility and the demand for redistribution: the POUM hypothesis. Quarterly Journal of Economics 116(2), 447-87.

Bowles, S. and H. Gintis (2000). Reciprocity, self-interest, and the welfare state. Nordic Journal of Political Economy 26, 33-53.

Brennan, G. (1973). Pareto desirable redistribution: the non-altruistic dimension. Public Choice 14(Spring), 43-67.

Buchanan, J. M. and G. Tullock (1962). The Calculus of Consent: Logical Foundations of Constitutional Democracy. Ann Arbor, Mich.: University of Michigan Press.

Cameron, A. C., J. B. Gelbach, and D. L. Miller (2006). Robust inference with multi-way clustering. Working Paper T0327, NBER. 
Cameron, A. C. and P. K. Trivedi (2005). Microeconometrics: Methods and Applications. Cambridge: Cambridge University Press.

Corneo, G. (2003). Wieso Umverteilung? Einsichten aus ökonometrischen Umfrageanalysen. Discussion Paper 2003/12, Universität Osnabrück, Fachbereich Wirtschaftswissenschaften.

Corneo, G. and H. P. Grüner (2000). Social limits to redistribution. American Economic Review 90(5), 1491-1507.

Corneo, G. and H. P. Grüner (2002). Individual preferences for political redistribution. Journal of Public Economics 83(1), 83-107.

Ferrer-i-Carbonell, A. and P. Frijters (2004). How important is methodology for the estimates of the determinants of happiness? Economic Journal 114, 641-659.

Fong, C. M. (2001). Social preferences, self-interest, and the demand for redistribution. Journal of Public Economics 82(2), 225-46.

Hausman, J. A. (1978). Specification tests in econometrics. Econometrica 46, 1251-1271.

Hochman, H. M. and J. D. Rodgers (1969). Pareto optimal redistribution. American Economic Review 59(4), 542-57.

Lee, W. and J. E. Roemer (2006). Racism and redistribution in the United States: a solution to the problem of American expectionalism. Journal of Public Economics 90, $1027-1052$.

Lind, J. T. (2007). Fractionalization and the size of government. Journal of Public Economics 91, 51-76.

Luttmer, E. F. P. (2001). Group loyalty and the taste for redistribution. Journal of Political Economy 109(3), 500-28.

Miller, D. (1992). Distributive justice: What the people think. Ethics 102(3), 555-93.

Olson, M. (1965). The Logic of Collective Action: Public Goods and the Theory of Groups. Cambridge, Mass.: Harvard University Press.

Piketty, T. (1995). Social mobility and redistributive politics. Quarterly Journal of Economics 110(3), 551-84.

Piketty, T. (1996a). Mobilité économique et attitudes politiques face à la redistribution. Working Paper 9603, Cepremap, Paris. 
Piketty, T. (1996b). The politics of redistribution: Recent developments and research perspectives. Prepared for the meeting of the McArthur Foundation Costs of Inequality Project, Boston, 3-5 May.

Piketty, T. (2003). Attitudes vis-à-vis des inégalités de revenu en France: existerait-il un consensus? Comprendre 4, 209-41.

Ravallion, M. and M. Lokshin (2000). Who wants to redistribute? The tunnel effect in 1990s Russia. Journal of Public Economics 76, 87-104.

Roemer, J. E. (1998). Why the poor do not expropriate the rich: an old argument in new garb. Journal of Public Economics 70(3), 399-424.

Roemer, J. E. and K. van der Straeten (2005). Xenophobia and distribution in France: A politico-economic analysis. Journal of Economics 86(1478), 95-144.

Roemer, J. E. and K. van der Straeten (2006). The political economy of xenophobia and distribution: the case of Denmark. Scandinavian Journal of Economics 108, 251-78.

Senik, C., H. Stichnoth, and K. Van der Straeten (2009). Immigration and natives' attitudes towards the welfare state: evidence from the European Social Survey. Social Indicators Research 91, 345-70.

Soroka, S. N., R. Johnston, and K. Banting (2004). Ethnicity, trust, and the welfare state. In P. Van Parijs (Ed.), Cultural Diversity versus Economic Solidarity, Brussels. De Boeck.

Stichnoth, H. and K. Van der Straeten (2009). Immigration and natives' attitudes towards redistribution: a review of the literature. Discussion paper 09-036, ZEW, Mannheim.

Thompson, S. B. (2006). Simple formulas for standard errors that cluster by both firm and time-series. Technical report, Harvard University.

Thurow, L. C. (1971). The income distribution as a pure public good. Quarterly Journal of Economics 85(2), 327-36.

Varian, H. (1980). Redistributive taxation as social insurance. Journal of Public Economics 14, 49-68.

Wagner, G. G., J. R. Frick, and J. Schupp (2007). The German Socio-Economic Panel Study (SOEP): Scope, evolution and enhancements. Schmollers Jahrbuch 127, 139169. 
White, H. (1980). A heteroskedasticity-consistent covariance matrix estimator and a direct test for heteroskedasticity. Econometrica 48, 817-838.

Wooldridge, J. M. (2002). Econometric Analysis of Cross Section and Panel Data. Cambridge, Mass.: M.I.T. Press. 


\section{A Appendix}

\section{A.1 Summary statistics}
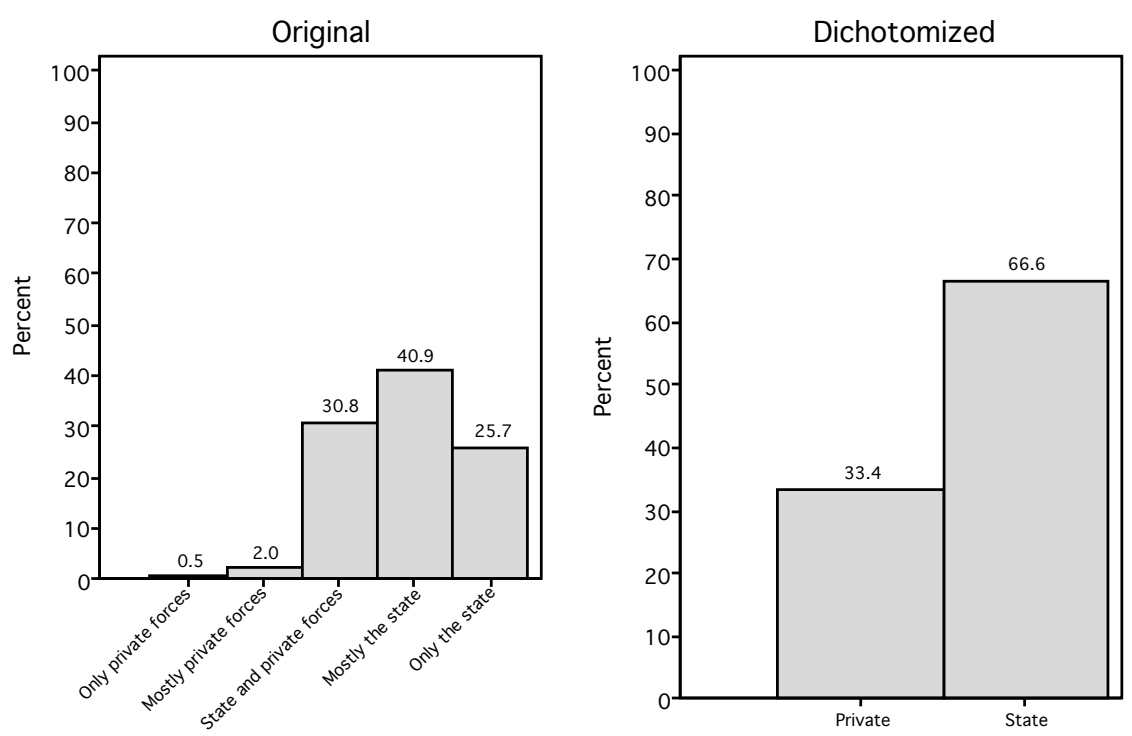

Figure 1: Responsibility for financial security of the unemployed
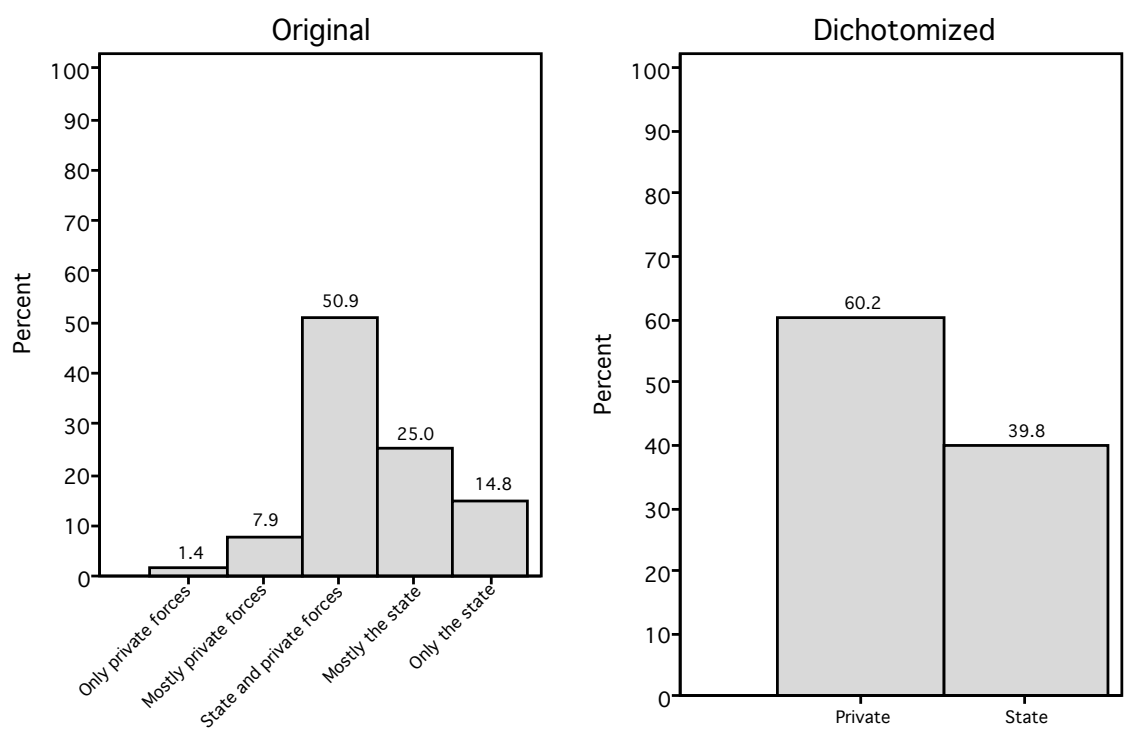

Figure 2: Responsibility for job creation 
Table 2: Regional variables

\begin{tabular}{llrrrr}
\hline Level & Variable & Mean & SD & Min & Max \\
\hline \multirow{3}{*}{ County } & Unemployment rate & 11.9 & 5.2 & 0.4 & 29.5 \\
& Foreigners per 100 residents & 8.2 & 5.6 & 0.4 & 26.0 \\
& Foreigners / 100 unemployed & 13.1 & 9.7 & 0.3 & 44.2 \\
& Unemployment rate & 12.1 & 4.9 & 5.1 & 25.5 \\
Regional planning unit & Foreigners per 100 residents & 8.3 & 4.8 & 1.3 & 17.5 \\
& Foreigners / 100 unemployed & 13.4 & 8.9 & 0.5 & 33.4 \\
& Unemployment rate & 11.9 & 4.6 & 6.8 & 21.1 \\
Federal state & Foreigners per 100 residents & 8.0 & 4.1 & 1.5 & 15.2 \\
& Foreigners / 100 unemployed & 13.1 & 7.7 & 1.0 & 23.9
\end{tabular}

Note: Own calculations based on Indikatoren und Karten zur Raumentwicklung, published by the Bundesamt fuer Bauwesen und Raumordnung; 1999 and 2004 editions of the CD-ROM. 
Table 3: Summary statistics

\begin{tabular}{|c|c|c|c|c|c|}
\hline Variable & Mean & SD & Min & Max & $\mathbf{N}$ \\
\hline State responsible: financial security unemployed & 0.67 & . & 0 & 1 & 32750 \\
\hline State responsible for job creation & 0.40 & . & 0 & 1 & 32759 \\
\hline Male & 0.48 & . & 0 & 1 & 33203 \\
\hline Age & 46.09 & 17.21 & 17 & 99 & 33203 \\
\hline Lived in East in 1989 & 0.31 & . & 0 & 1 & 31030 \\
\hline Lives in East & 0.28 & . & 0 & 1 & 33202 \\
\hline Born abroad & 0.07 & . & 0 & 1 & 32496 \\
\hline Foreign nationality & 0.00 & . & 0 & 0 & 33203 \\
\hline Household size & 2.81 & 1.27 & 1 & 12 & 33203 \\
\hline Single & 0.24 & . & 0 & 1 & 33200 \\
\hline Married & 0.61 & . & 0 & 1 & 33200 \\
\hline Married but separated & 0.02 & . & 0 & 1 & 33200 \\
\hline Divorced & 0.07 & . & 0 & 1 & 33200 \\
\hline Widowed & 0.07 & . & 0 & 1 & 33200 \\
\hline Household net income (month) & 2739.93 & 1528.50 & 480 & 10428 & 31318 \\
\hline Working & 0.59 & . & 0 & 1 & 33203 \\
\hline Not working, unemployed & 0.05 & . & 0 & 1 & 33203 \\
\hline Not working, other reasons & 0.36 & . & 0 & 1 & 33203 \\
\hline Civil servant & 0.05 & . & 0 & 1 & 33178 \\
\hline Self-employed & 0.06 & . & 0 & 1 & 33195 \\
\hline Owns residence & 0.52 & . & 0 & 1 & 33203 \\
\hline Worried overall economy & 1.68 & 0.60 & 1 & 3 & 33052 \\
\hline Worried own economic situation & 2.11 & 0.68 & 1 & 3 & 33043 \\
\hline No degree yet & 0.03 & . & 0 & 1 & 32627 \\
\hline Dropout, no degree & 0.02 & . & 0 & 1 & 32627 \\
\hline Hauptschule & 0.38 & . & 0 & 1 & 32627 \\
\hline Realschule & 0.31 & . & 0 & 1 & 32627 \\
\hline Abitur & 0.23 & . & 0 & 1 & 32627 \\
\hline Other degree & 0.04 & . & 0 & 1 & 32627 \\
\hline College degree & 0.19 & . & 0 & 1 & 32811 \\
\hline Vocational degree & 0.66 & . & 0 & 1 & 32811 \\
\hline Year $=1997$ & 0.34 & . & 0 & 1 & 33203 \\
\hline Year $=2002$ & 0.66 & . & 0 & 1 & 33203 \\
\hline
\end{tabular}




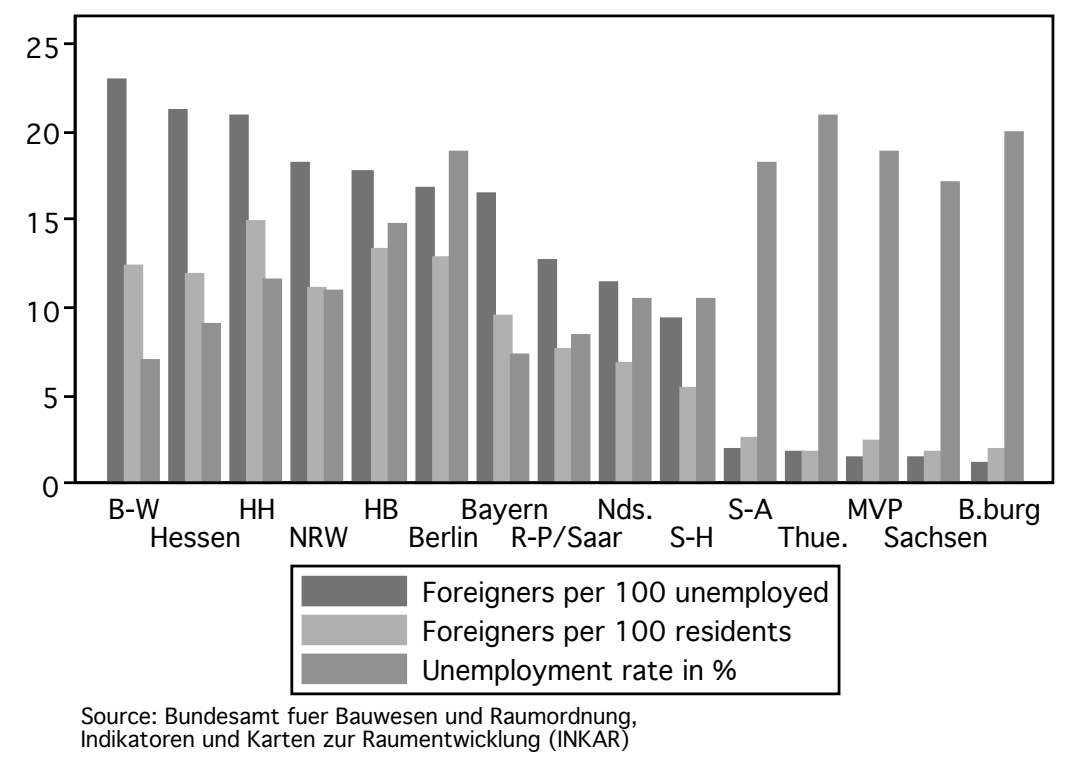

Figure 3: Regional indicators for federal states, 1997 and 2002 pooled 


\section{A.2 Variance decomposition}

Table 4: Decomposition of overall variance into variance between and variance within individuals: whole sample

\begin{tabular}{lrrrrr}
\hline \multirow{2}{*}{ Area } & \multicolumn{4}{c}{ Sum of squares } & Percent \\
\\
\hline County & Total & Between & Within & Within & N \\
Regional planning unit & 2466337 & 2355851 & 110486 & 4.48 & 26437 \\
Federal state & 2127199 & 2093173 & 34026 & 1.60 & 26796 \\
& 1833126 & 1811295 & 21831 & 1.19 & 31253 \\
\hline
\end{tabular}

Note: Total sum of squares $=$ sum of squared deviations of individual values from overall mean. Between sum of squares $=$ sum of squared deviations of individual means from overall mean. Within sum of squares $=$ sum of squared deviations of individual values from individual means.

Table 5: Decomposition of overall variance into variance between and variance within individuals: only individuals who took part in both waves

\begin{tabular}{lrrrrr}
\hline \multirow{2}{*}{ Area } & \multicolumn{3}{c}{ Sum of squares } & Percent & \\
\hline County & Total & Between & Within & Within & N \\
Regional planning unit & 1233164 & 1122678 & 110486 & 8.96 & 12770 \\
Federal state & 1072668 & 1038642 & 34026 & 3.17 & 12999 \\
\hline
\end{tabular}

Note: Total sum of squares = sum of squared deviations of individual values from overall mean. Between sum of squares $=$ sum of squared deviations of individual means from overall mean. Within sum of squares $=$ sum of squared deviations of individual values from individual means. 
A.3 Cross tabulations 


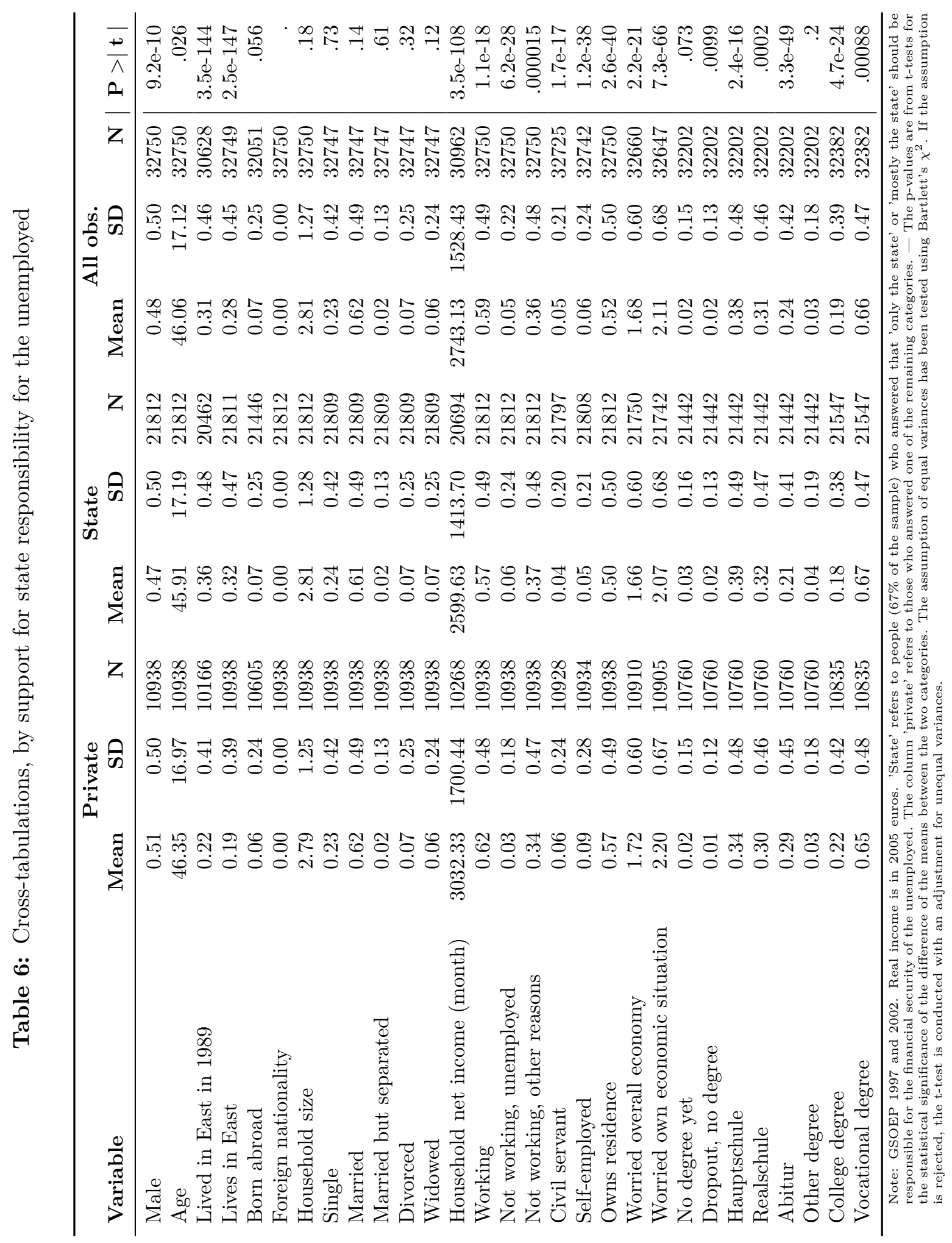




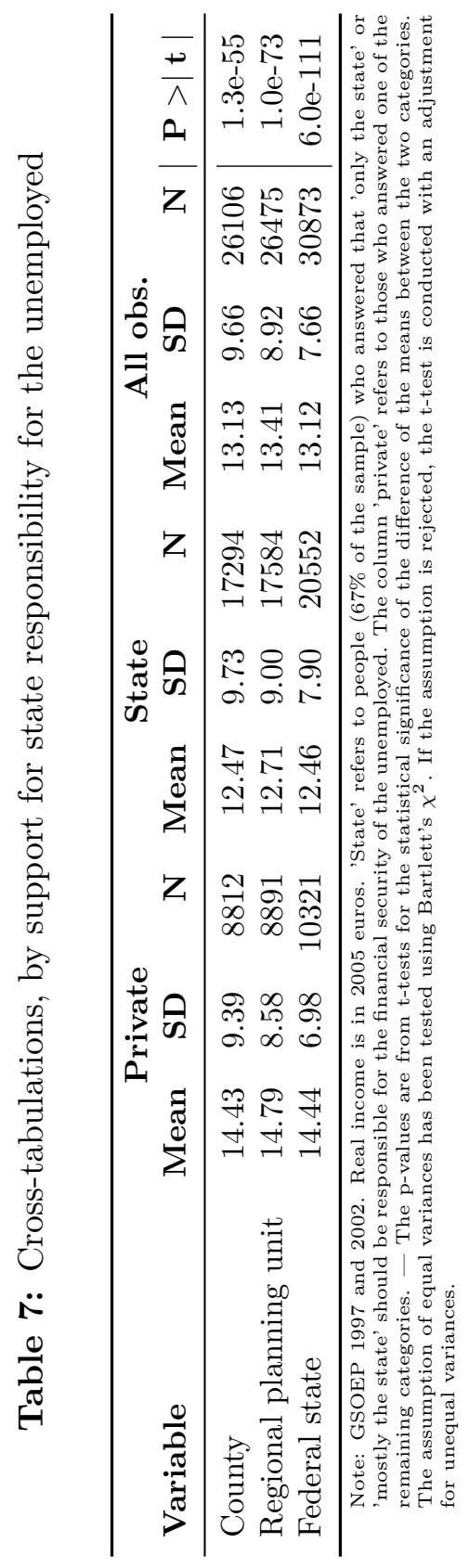




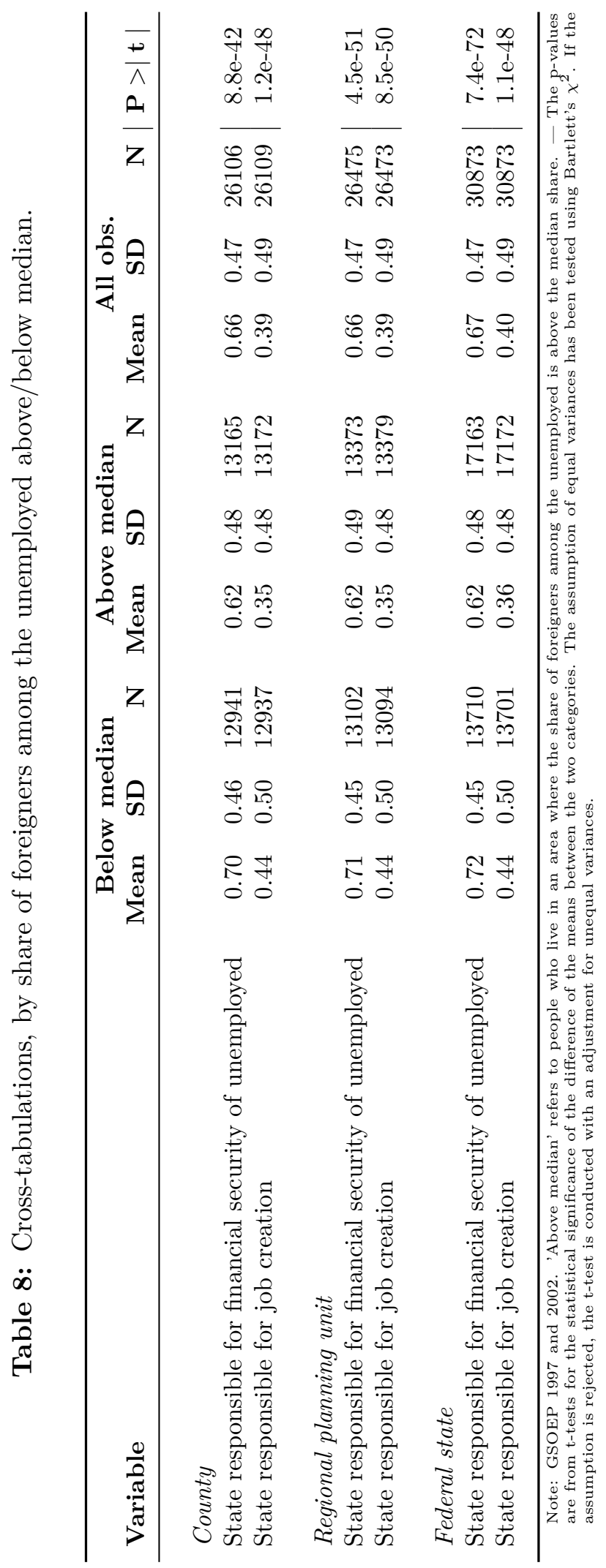




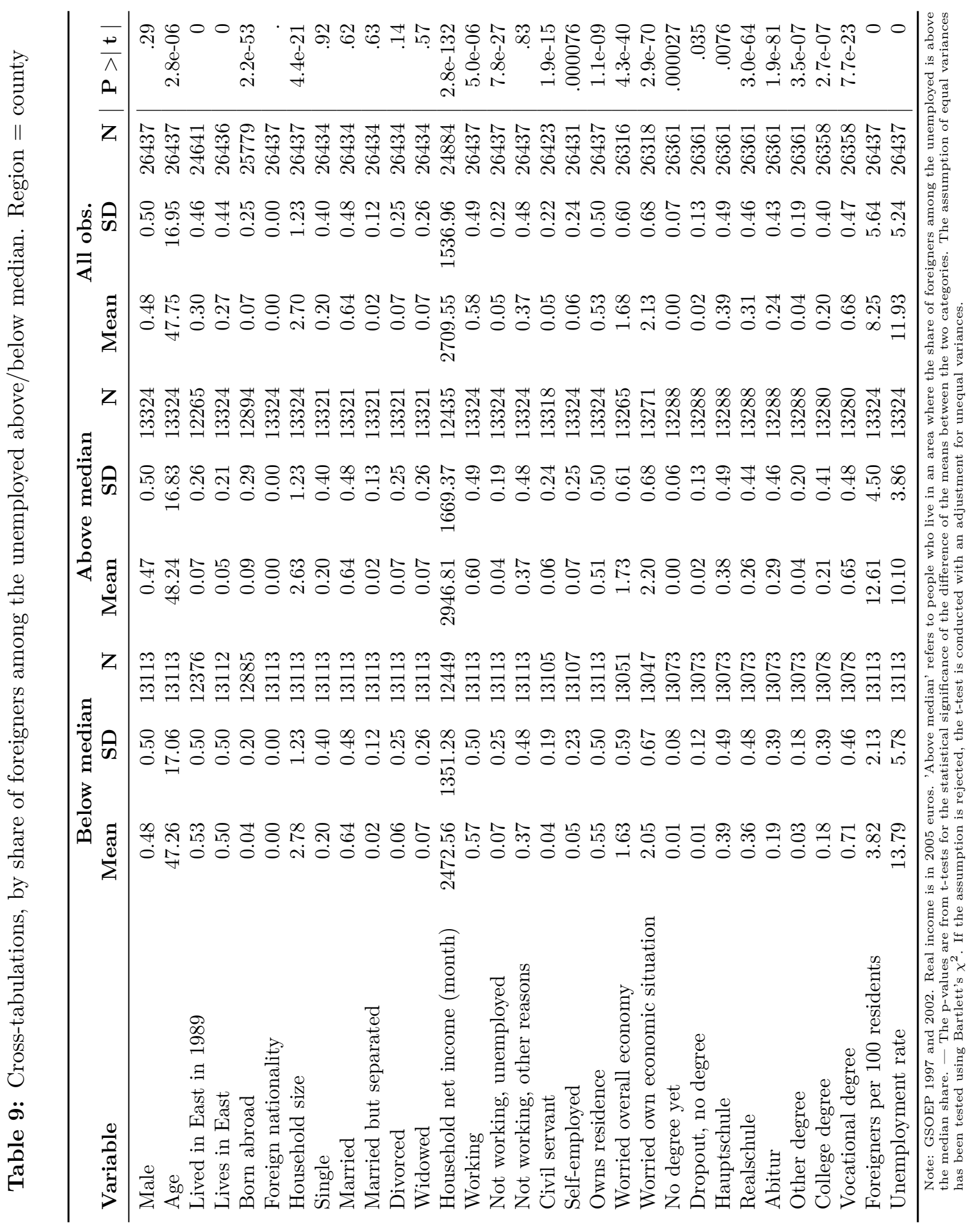


A.4 Detailed results for main specification 


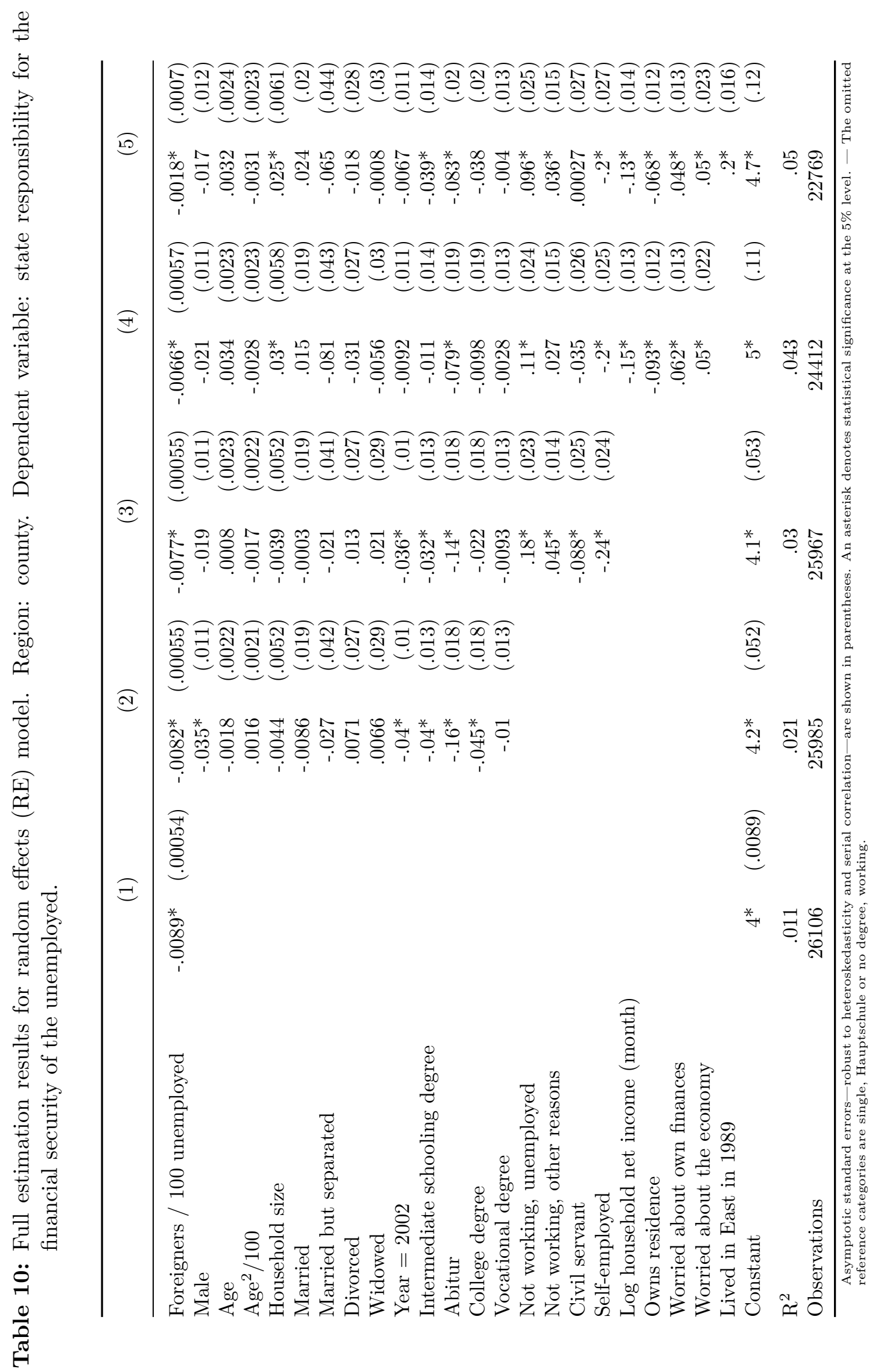




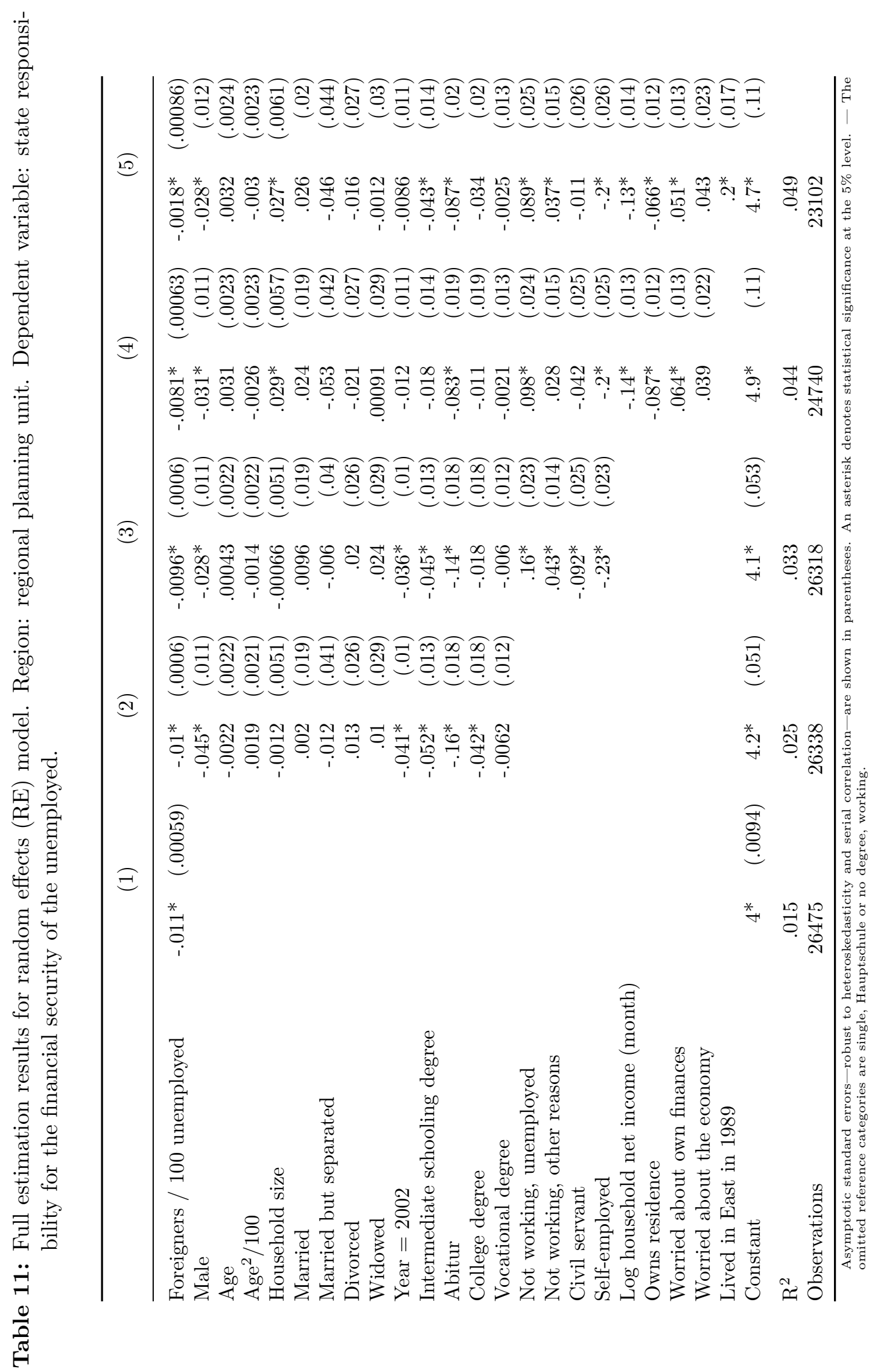




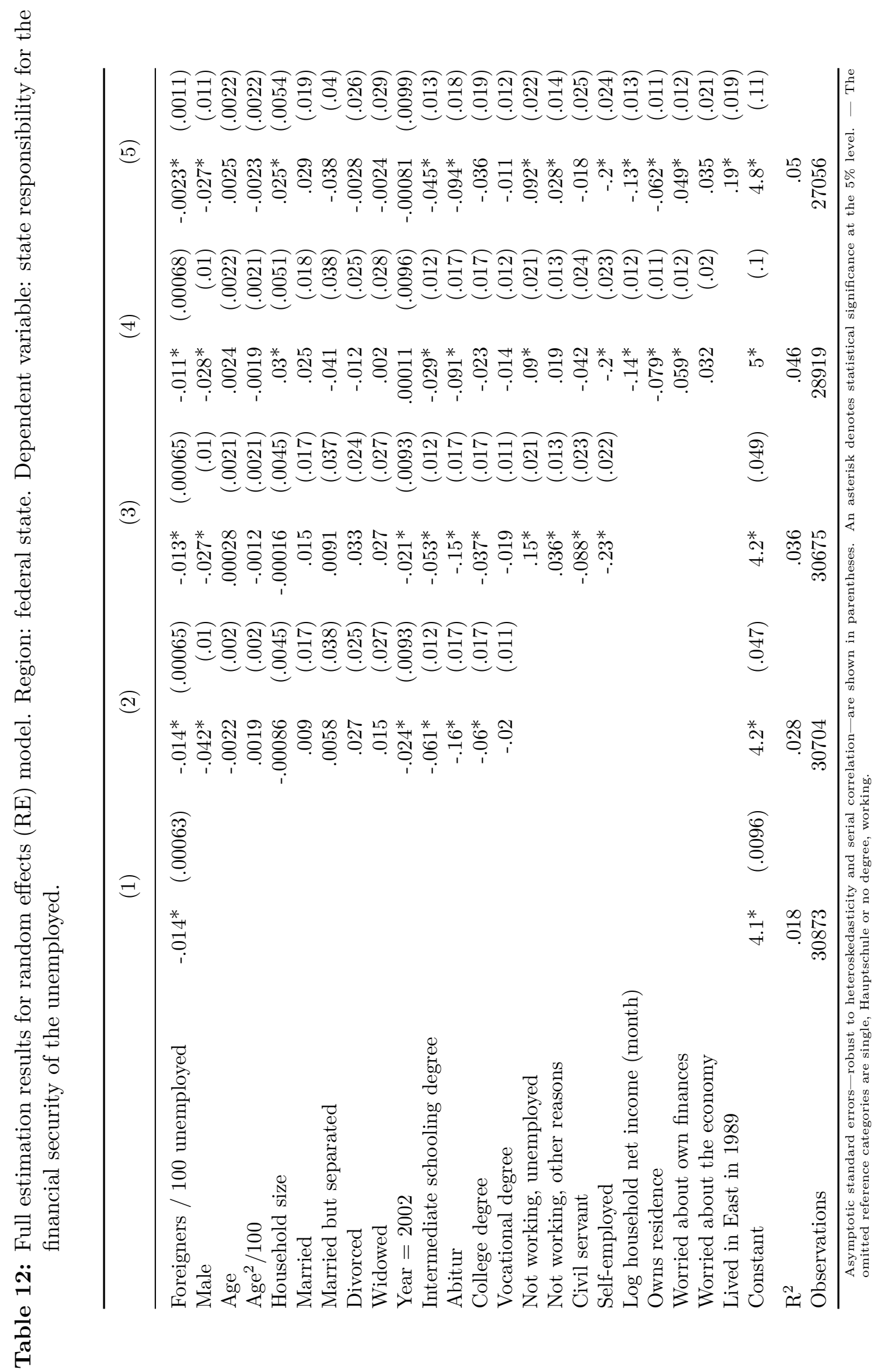




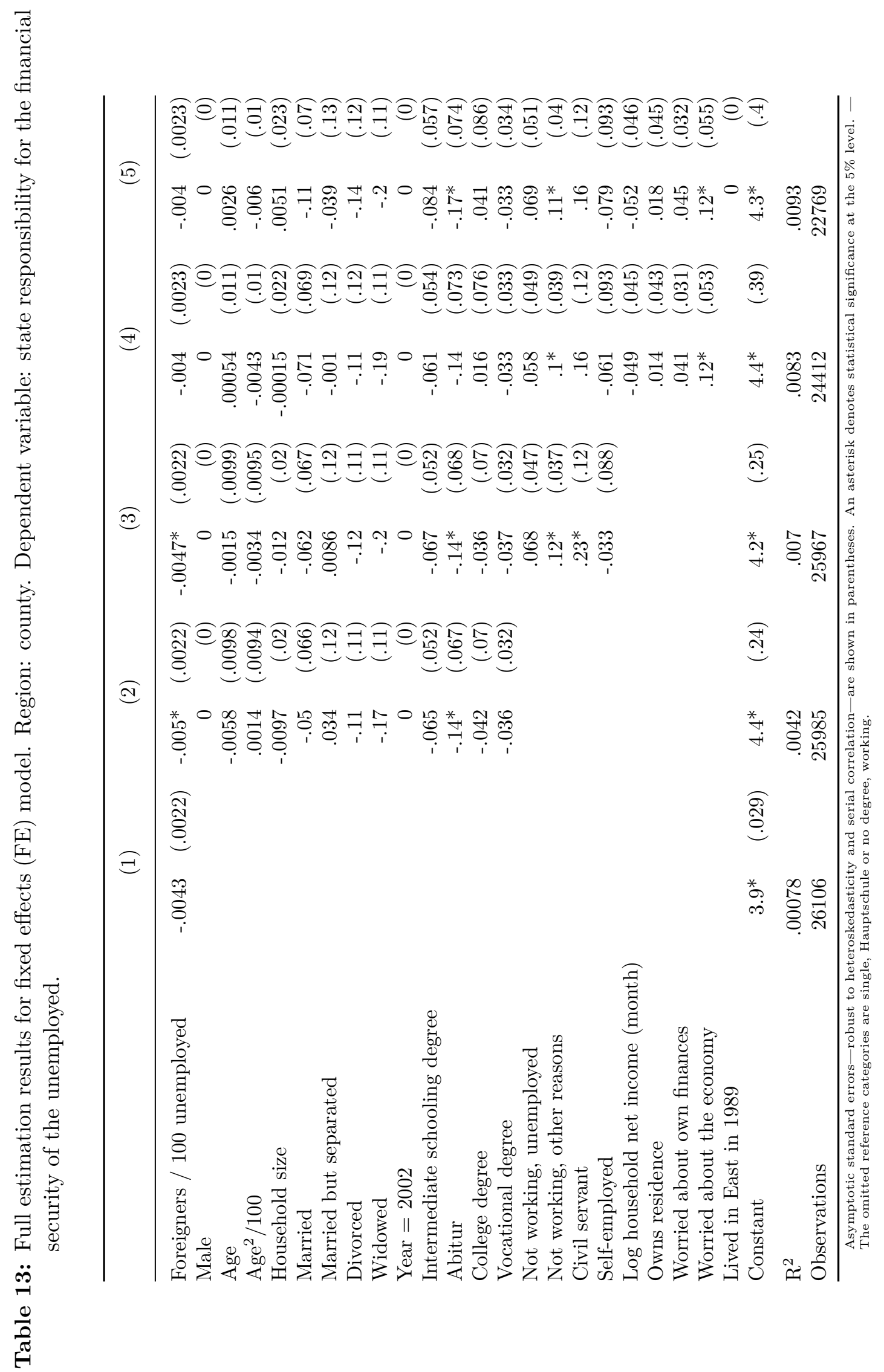




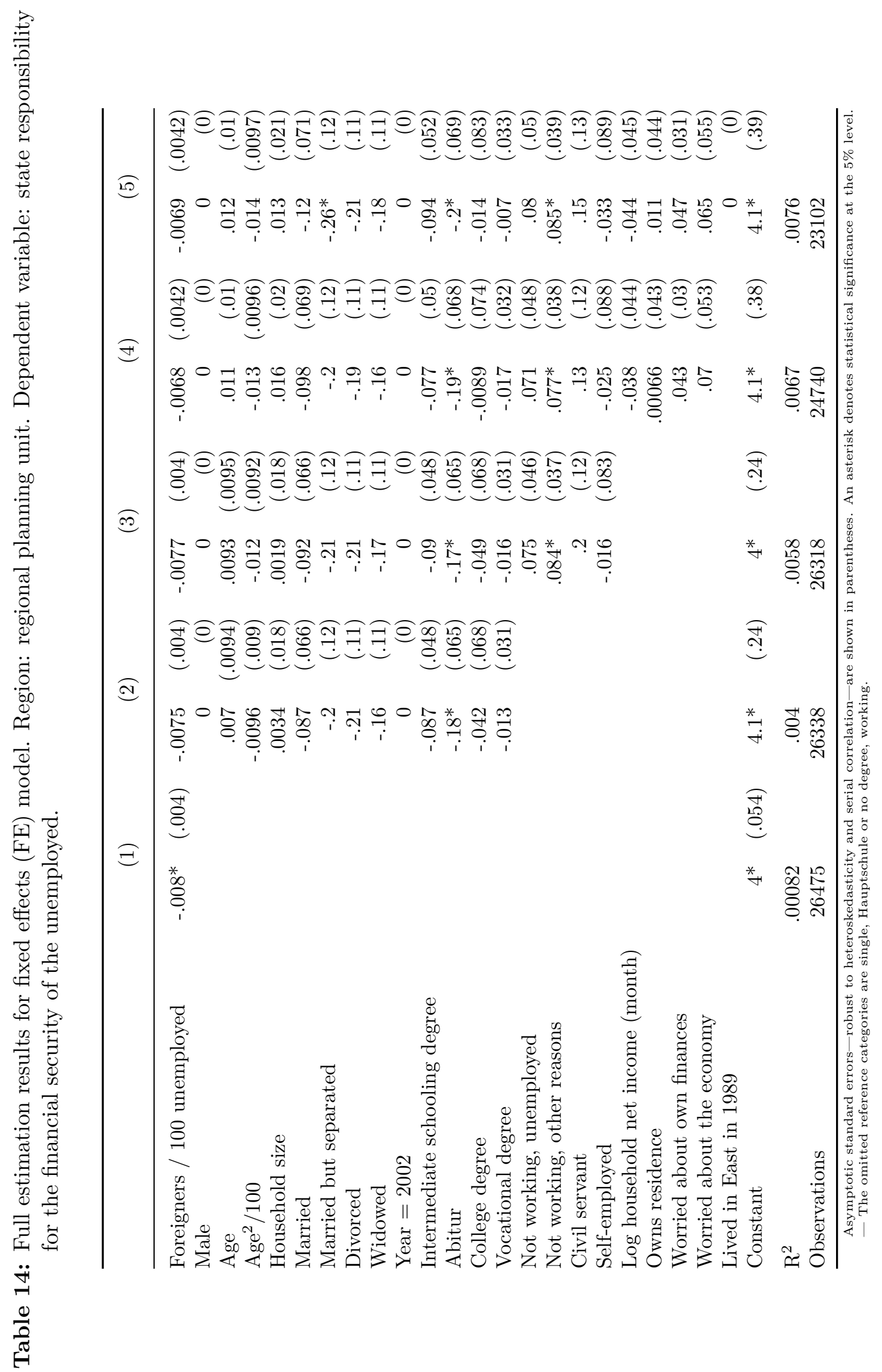




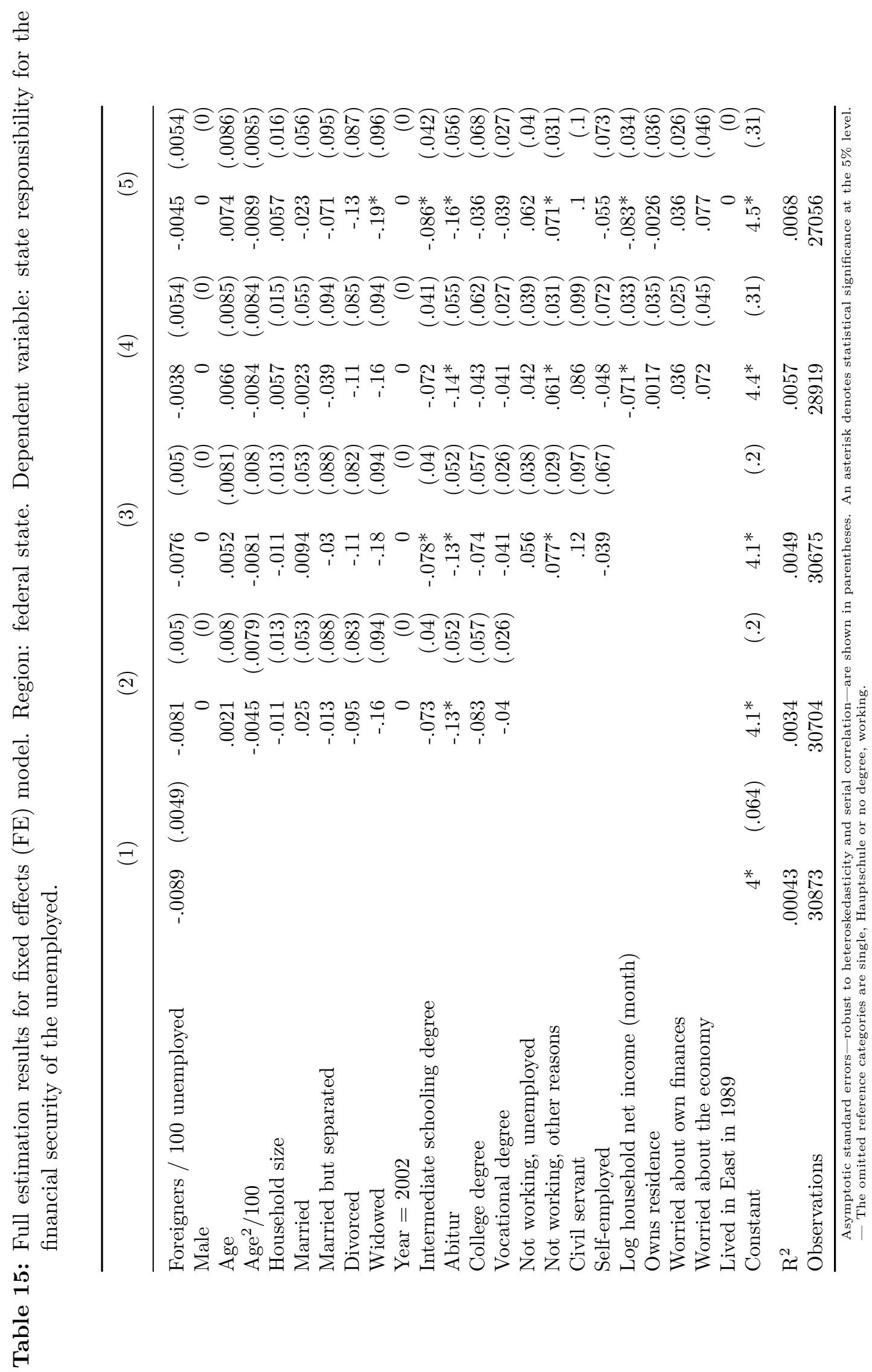




\section{A.5 Hausman tests}

Table 16: Hausman tests using Wald tests in an auxiliary regression

\begin{tabular}{lrr}
\hline & Financial Security & Job Creation \\
\hline County & $33.6^{*}$ & $36.4^{*}$ \\
& $(.029)$ & $(.014)$ \\
Regional planning unit & 31.0 & $37.7^{*}$ \\
& $(.056)$ & $(.0096)$ \\
Federal state & $32.6^{*}$ & $43.6^{*}$ \\
& $(.038)$ & $(.0017)$
\end{tabular}

Note: The table reports results from Wald tests of $\gamma=\mathbf{0}$ in the auxiliary regression of equation (9) on page 20. In this regression, a panel-robust variancecovariance estimator is used. The first line in each cell shows the test statistic, the second line shows the associated p-value. An asterisk denotes statistical significance at the $5 \%$ level.

\section{A.6 Robustness checks}

Table 17: Overview of results for the dependent variable 'state responsibility for job creation'

\begin{tabular}{lcccc}
\hline & \multicolumn{2}{c}{ Bivariate } & \multicolumn{2}{c}{ Full controls } \\
& $\mathrm{RE}$ & $\mathrm{FE}$ & $\mathrm{RE}$ & $\mathrm{FE}$ \\
\hline County & $-.01^{*}$ & -.0011 & $-.0022^{*}$ & -.0017 \\
& $(.00058)$ & $(.0022)$ & $(.00074)$ & $(.0023)$ \\
Regional planning unit & $-.012^{*}$ & -.0033 & $-.0022^{*}$ & -.0036 \\
& $(.00063)$ & $(.0037)$ & $(.0009)$ & $(.0039)$ \\
Federal state & $-.015^{*}$ & -.0038 & $-.0028^{*}$ & -.0071 \\
& $(.0007)$ & $(.0047)$ & $(.0012)$ & $(.0049)$ \\
\hline
\end{tabular}

Note: Asymptotic standard errors-robust to heteroskedasticity and serial correlation-are shown in parentheses. An asterisk denotes statistical significance at the $5 \%$ level. 
Table 18: Overview of results for the dependent variable 'state responsibility for the financial security for the unemployed' - Only people who are observed in the same area in both 1997 and 2002.

\begin{tabular}{lcccc}
\hline & \multicolumn{2}{c}{ Bivariate } & \multicolumn{2}{c}{ Full controls } \\
& $\mathrm{RE}$ & $\mathrm{FE}$ & $\mathrm{RE}$ & $\mathrm{FE}$ \\
\hline County & $-.0085^{*}$ & -.0018 & -.0016 & -.0023 \\
& $(.0015)$ & $(.0057)$ & $(.0018)$ & $(.0052)$ \\
Regional planning unit & $-.012^{*}$ & -.015 & -.003 & -.016 \\
& $(.0018)$ & $(.02)$ & $(.0021)$ & $(.02)$ \\
Federal state & $-.016^{*}$ & $-.056^{*}$ & $-.0054^{*}$ & $-.053^{*}$ \\
& $(.002)$ & $(.025)$ & $(.0018)$ & $(.023)$ \\
\hline
\end{tabular}

Note: Asymptotic standard errors - robust to heteroskedasticity and to both serial correlation and correlation at the area-level-are shown in parentheses. An asterisk denotes statistical significance at the $5 \%$ level.

Table 19: Overview of results for the dependent variable 'state responsibility for job creation' - Only people who are observed in the same area in both 1997 and 2002.

\begin{tabular}{lcccc}
\hline & \multicolumn{2}{c}{ Bivariate } & \multicolumn{2}{c}{ Full controls } \\
& $\mathrm{RE}$ & $\mathrm{FE}$ & $\mathrm{RE}$ & $\mathrm{FE}$ \\
\hline County & $-.01^{*}$ & $-.0043^{*}$ & -.003 & $-.0044^{*}$ \\
& $(.0015)$ & $(.0019)$ & $(.0017)$ & $(.0021)$ \\
Regional planning unit & $-.012^{*}$ & -.011 & -.0015 & -.021 \\
& $(.0019)$ & $(.018)$ & $(.0023)$ & $(.021)$ \\
Federal state & $-.016^{*}$ & -.011 & -.0044 & -.025 \\
& $(.0014)$ & $(.018)$ & $(.0037)$ & $(.021)$ \\
\hline
\end{tabular}

Note: Asymptotic standard errors - robust to heteroskedasticity and to both serial correlation and correlation at the area-level-are shown in parentheses. An asterisk denotes statistical significance at the $5 \%$ level. 
Table 20: Overview of results for the dependent variable 'state responsibility for the financial security for the unemployed.' - Only people who lived in East Germany in 1989.

\begin{tabular}{lcccc}
\hline & \multicolumn{2}{c}{ Bivariate } & \multicolumn{2}{c}{ Full controls } \\
& $\mathrm{RE}$ & $\mathrm{FE}$ & $\mathrm{RE}$ & $\mathrm{FE}$ \\
\hline County & $-.0038^{*}$ & -.0036 & -.0024 & -.0037 \\
& $(.0013)$ & $(.0027)$ & $(.0013)$ & $(.0028)$ \\
Regional planning unit & -.0022 & -.0064 & .0015 & -.0036 \\
& $(.0016)$ & $(.0055)$ & $(.0017)$ & $(.0057)$ \\
Federal state & $-.005^{*}$ & -.011 & -.00042 & -.00012 \\
& $(.0016)$ & $(.0057)$ & $(.0017)$ & $(.0067)$ \\
\hline
\end{tabular}

Note: Asymptotic standard errors - robust to heteroskedasticity and serial correlation - are shown in parentheses. An asterisk denotes statistical significance at the $5 \%$ level.

Table 21: Overview of results for the dependent variable 'state responsibility for the financial security for the unemployed. - Only people who lived in West Germany in 1989.

\begin{tabular}{lcccc}
\hline & \multicolumn{2}{c}{ Bivariate } & \multicolumn{2}{c}{ Full controls } \\
& $\mathrm{RE}$ & $\mathrm{FE}$ & $\mathrm{RE}$ & $\mathrm{FE}$ \\
\hline County & $-.0021^{*}$ & -.0059 & -.0013 & -.0057 \\
& $(.00078)$ & $(.0039)$ & $(.00083)$ & $(.0042)$ \\
Regional planning unit & $-.0036^{*}$ & -.0099 & $-.0023^{*}$ & -.01 \\
& $(.00096)$ & $(.0059)$ & $(.001)$ & $(.0064)$ \\
Federal state & -.0021 & -.0077 & -.0018 & -.0046 \\
& $(.0015)$ & $(.0092)$ & $(.0015)$ & $(.01)$ \\
\hline
\end{tabular}

Note: Asymptotic standard errors - robust to heteroskedasticity and serial correlation - are shown in parentheses. An asterisk denotes statistical significance at the $5 \%$ level. 
Table 22: Overview of results for the dependent variable 'state responsibility for the financial security for the unemployed.' - Only people who currently live in East Germany.

\begin{tabular}{lcccc}
\hline & \multicolumn{2}{c}{ Bivariate } & \multicolumn{2}{c}{ Full controls } \\
& $\mathrm{RE}$ & $\mathrm{FE}$ & $\mathrm{RE}$ & $\mathrm{FE}$ \\
\hline County & -.0014 & -.0024 & -.0006 & -.0027 \\
& $(.0014)$ & $(.0028)$ & $(.0015)$ & $(.0028)$ \\
Regional planning unit & .0017 & -.0082 & $.006^{*}$ & -.0048 \\
& $(.002)$ & $(.0071)$ & $(.0021)$ & $(.0073)$ \\
Federal state & .0017 & $-.027^{*}$ & $.007^{*}$ & -.011 \\
& $(.0023)$ & $(.013)$ & $(.0025)$ & $(.016)$ \\
\hline
\end{tabular}

Note: Asymptotic standard errors - robust to heteroskedasticity and serial correlation - are shown in parentheses. An asterisk denotes statistical significance at the $5 \%$ level.

Table 23: Overview of results for the dependent variable 'state responsibility for the financial security for the unemployed.' - Only people who currently live in West Germany.

\begin{tabular}{lcccc}
\hline & \multicolumn{2}{c}{ Bivariate } & \multicolumn{2}{c}{ Full controls } \\
& $\mathrm{RE}$ & $\mathrm{FE}$ & $\mathrm{RE}$ & $\mathrm{FE}$ \\
\hline County & $-.0023^{*}$ & -.0054 & -.0012 & -.0057 \\
& $(.00074)$ & $(.0038)$ & $(.00082)$ & $(.0042)$ \\
Regional planning unit & $-.0037^{*}$ & -.0069 & -.0019 & -.0063 \\
& $(.00091)$ & $(.0056)$ & $(.00099)$ & $(.0059)$ \\
Federal state & -.0027 & -.00042 & -.0011 & .00035 \\
& $(.0015)$ & $(.012)$ & $(.0016)$ & $(.013)$
\end{tabular}

Note: Asymptotic standard errors-robust to heteroskedasticity and serial correlation - are shown in parentheses. An asterisk denotes statistical significance at the $5 \%$ level. 
Table 24: Overview of results for the dependent variable 'state responsibility for the financial security for the unemployed'

\begin{tabular}{lcccc}
\hline & \multicolumn{2}{c}{ Aggregate } & \multicolumn{2}{c}{ Area dummies } \\
& $\mathrm{RE}$ & $\mathrm{FE}$ & $\mathrm{RE}$ & $\mathrm{FE}$ \\
\hline County & -.00077 & -.0034 & -.00077 & -.0034 \\
& $(.00072)$ & $(.003)$ & $(.00072)$ & $(.003)$ \\
Regional planning unit & .000013 & -.0028 & .000013 & -.0028 \\
& $(.00092)$ & $(.0047)$ & $(.00092)$ & $(.0047)$ \\
Federal state & -.00022 & -.0077 & -.00022 & -.0077 \\
& $(.0013)$ & $(.0064)$ & $(.0013)$ & $(.0064)$ \\
\hline
\end{tabular}

Note: Asymptotic standard errors-robust to heteroskedasticity and serial correlation - are shown in parentheses. An asterisk denotes statistical significance at the $5 \%$ level.

Table 25: Overview of results for the dependent variable 'state responsibility for job creation'

\begin{tabular}{lcccc}
\hline & \multicolumn{2}{c}{ Aggregate } & \multicolumn{2}{c}{ Area dummies } \\
& $\mathrm{RE}$ & $\mathrm{FE}$ & $\mathrm{RE}$ & $\mathrm{FE}$ \\
\hline County & -.0013 & .0038 & -.0013 & .0038 \\
& $(.00076)$ & $(.003)$ & $(.00076)$ & $(.003)$ \\
Regional planning unit & -.0014 & -.0007 & -.0014 & -.0007 \\
& $(.00096)$ & $(.0044)$ & $(.00096)$ & $(.0044)$ \\
Federal state & $-.0032^{*}$ & -.01 & $-.0032^{*}$ & -.01 \\
& $(.0014)$ & $(.0059)$ & $(.0014)$ & $(.0059)$ \\
\hline
\end{tabular}

Note: Asymptotic standard errors - robust to heteroskedasticity and serial correlation-are shown in parentheses. An asterisk denotes statistical significance at the $5 \%$ level. 


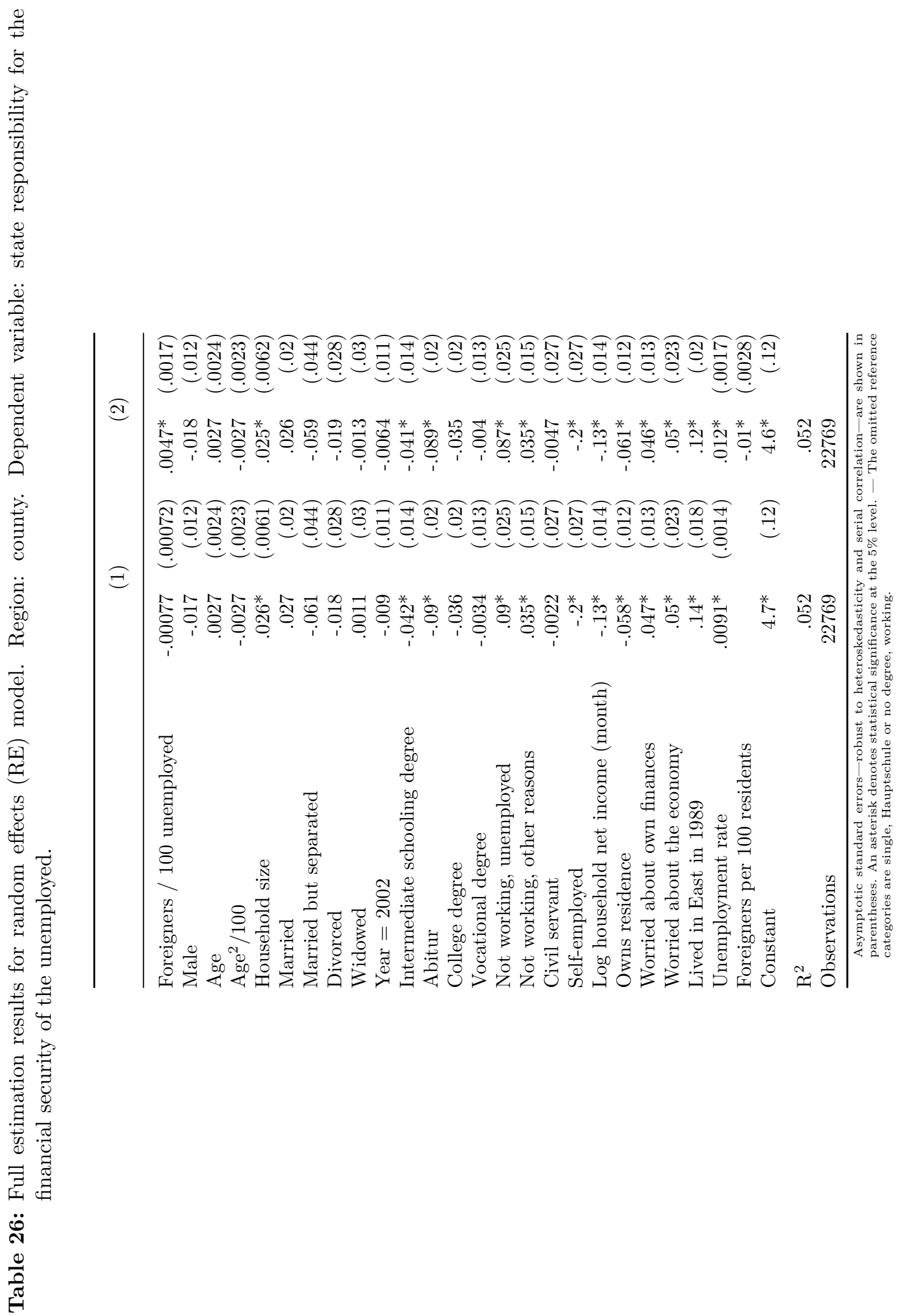




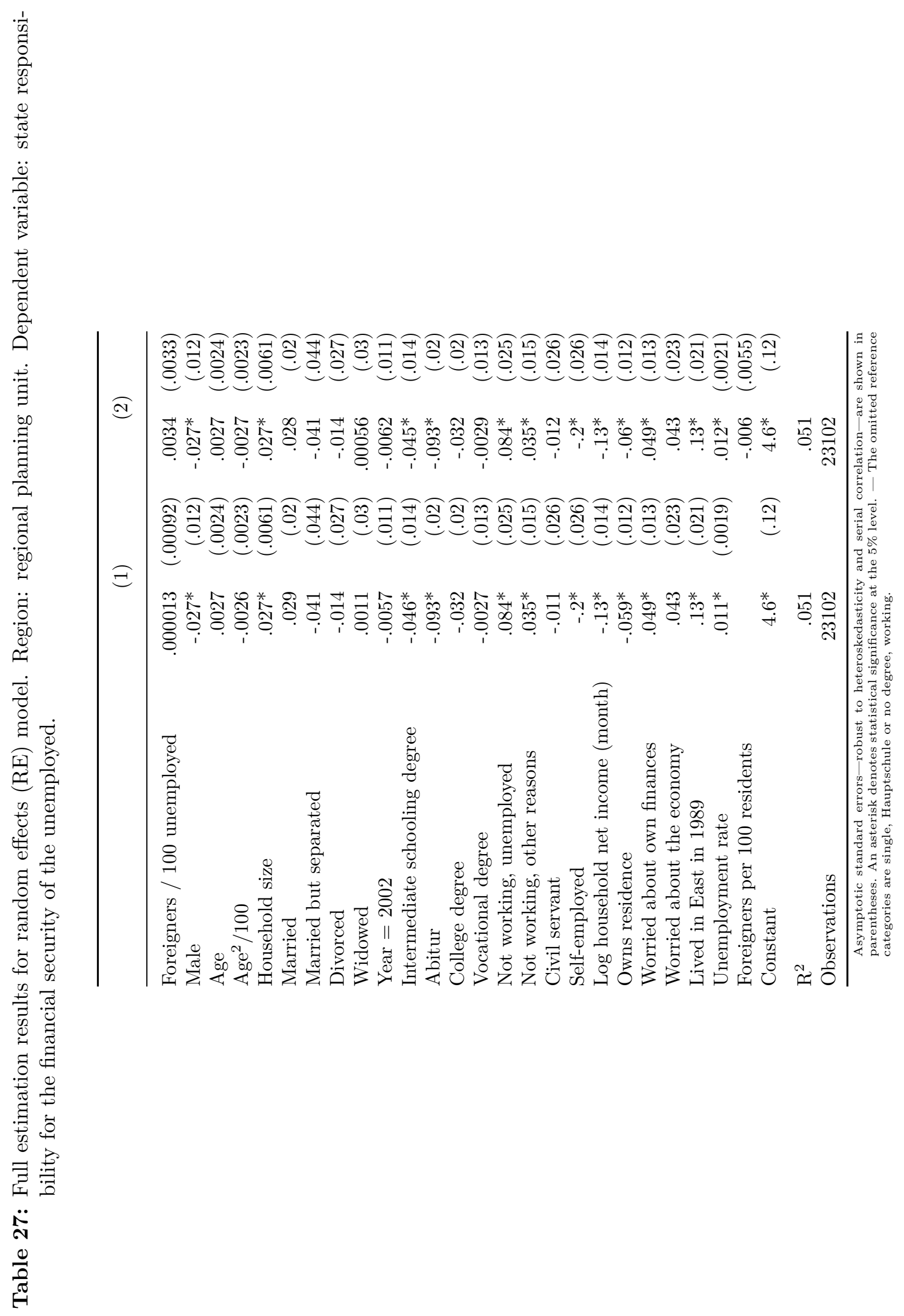




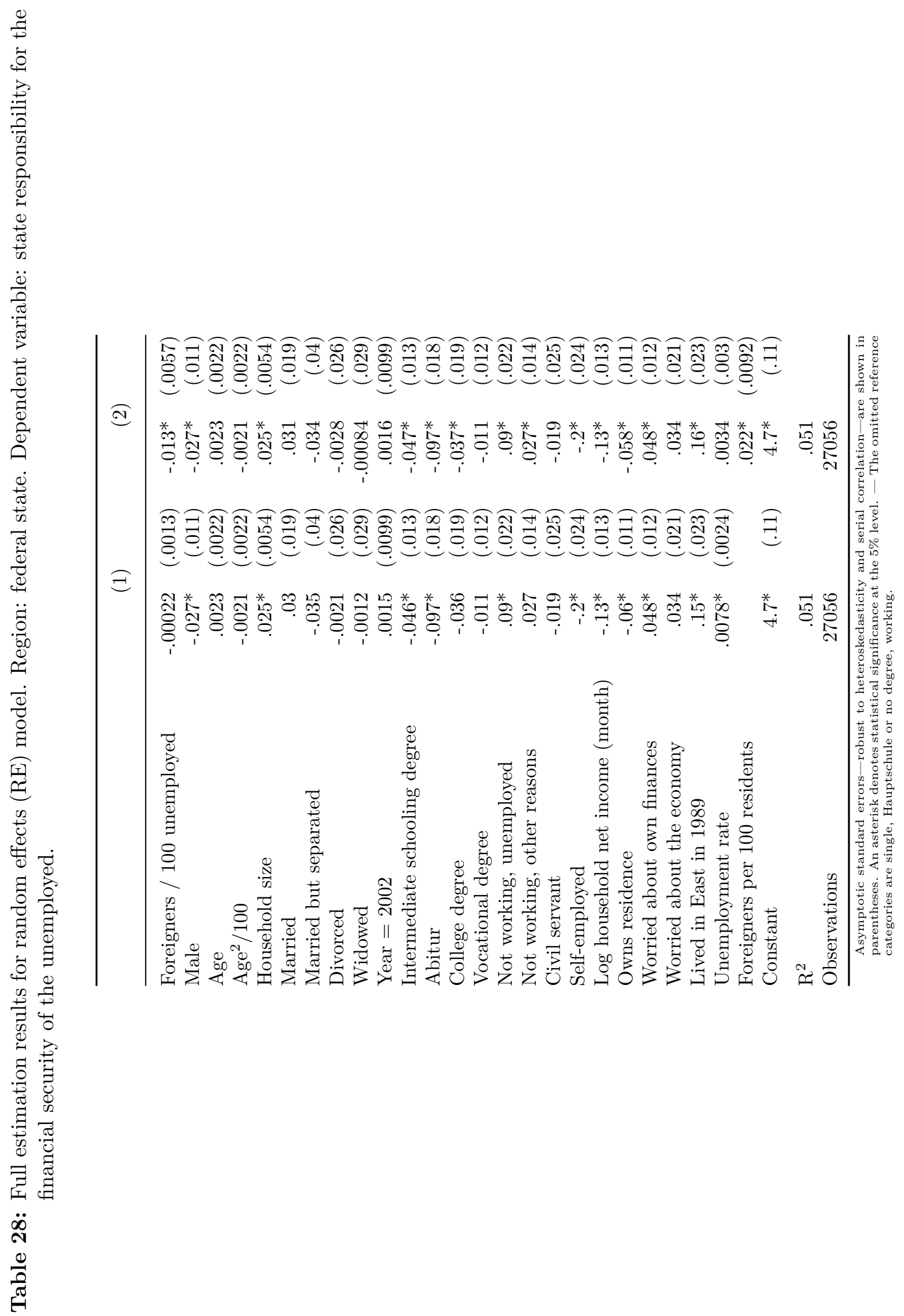




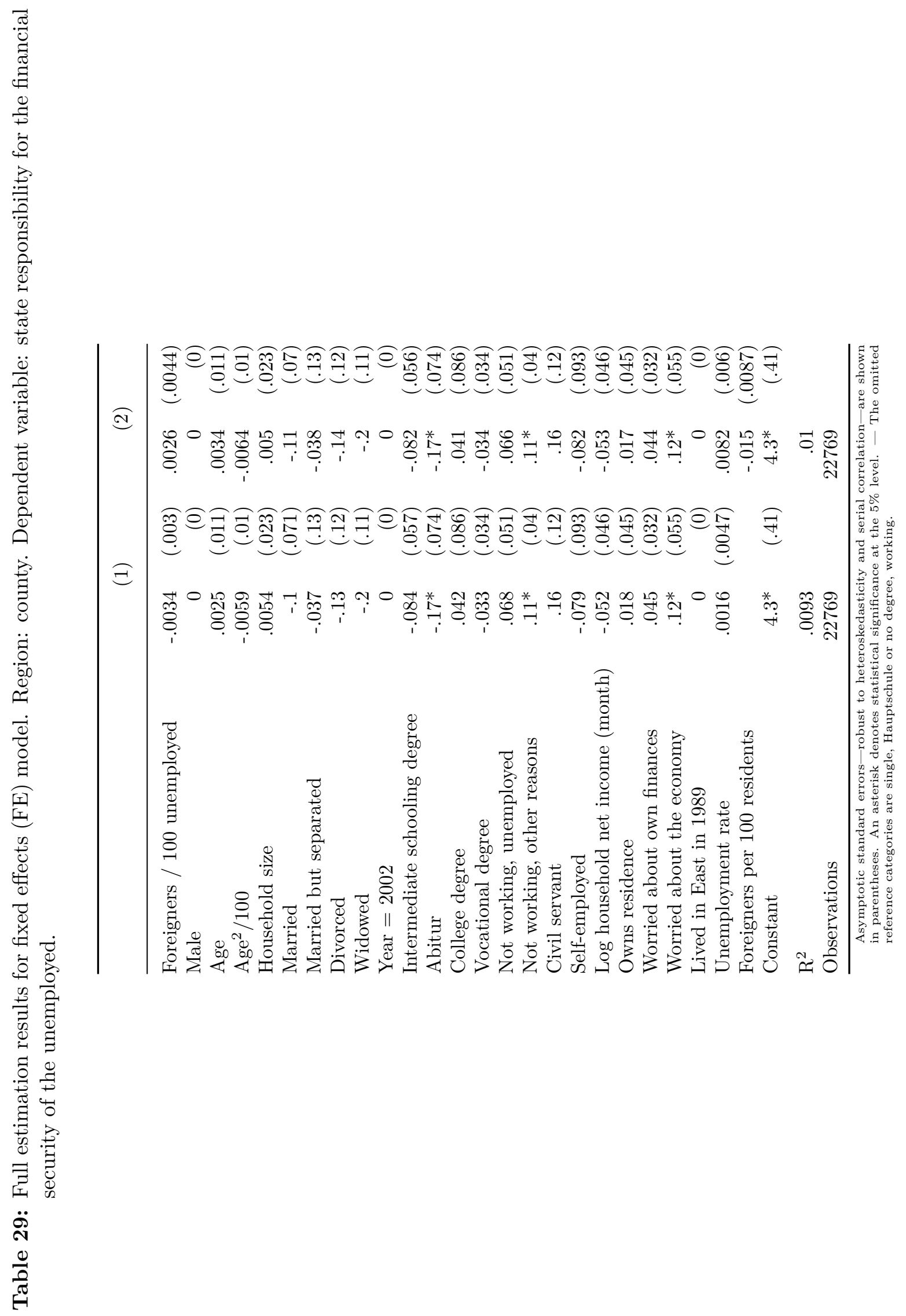




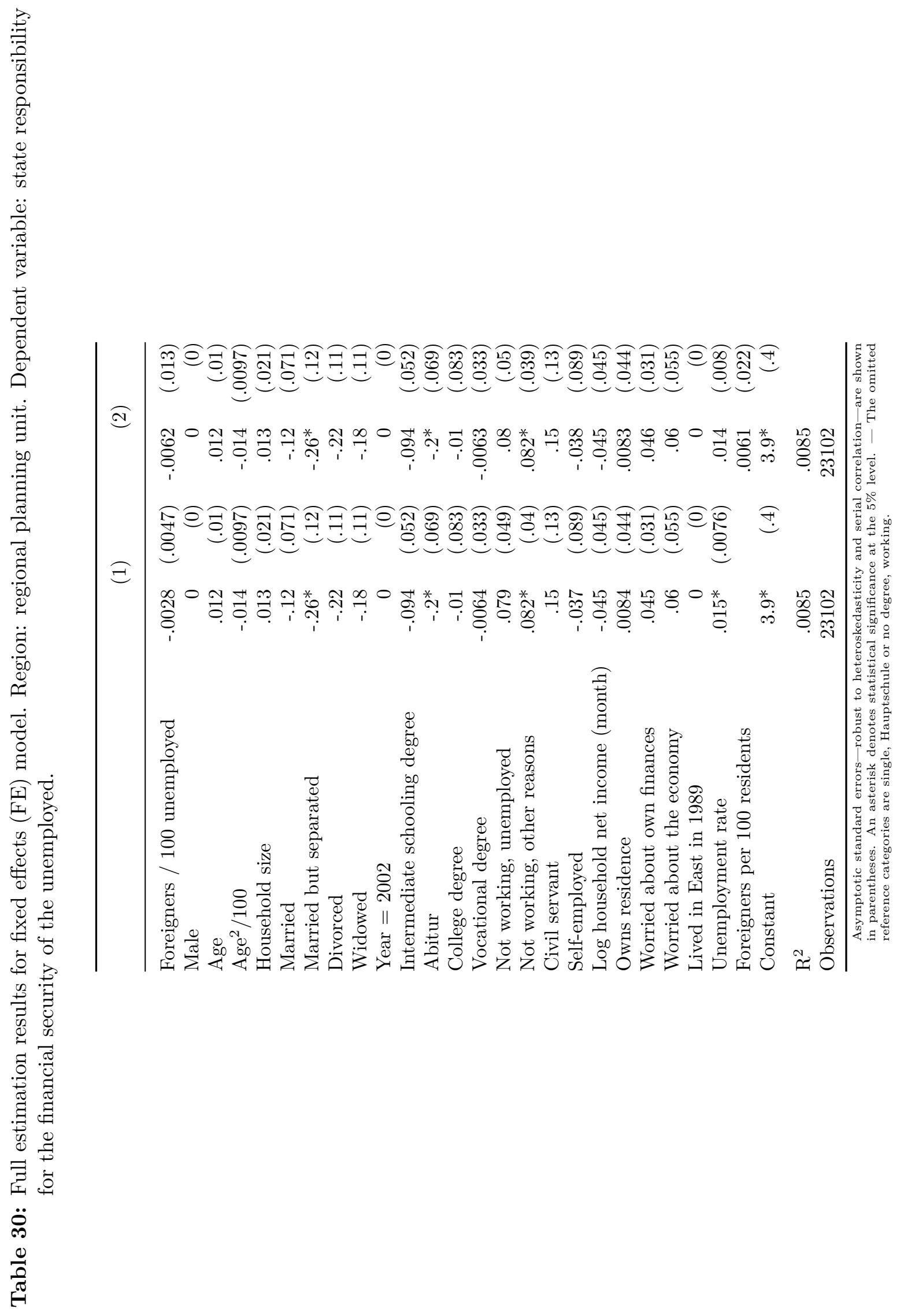




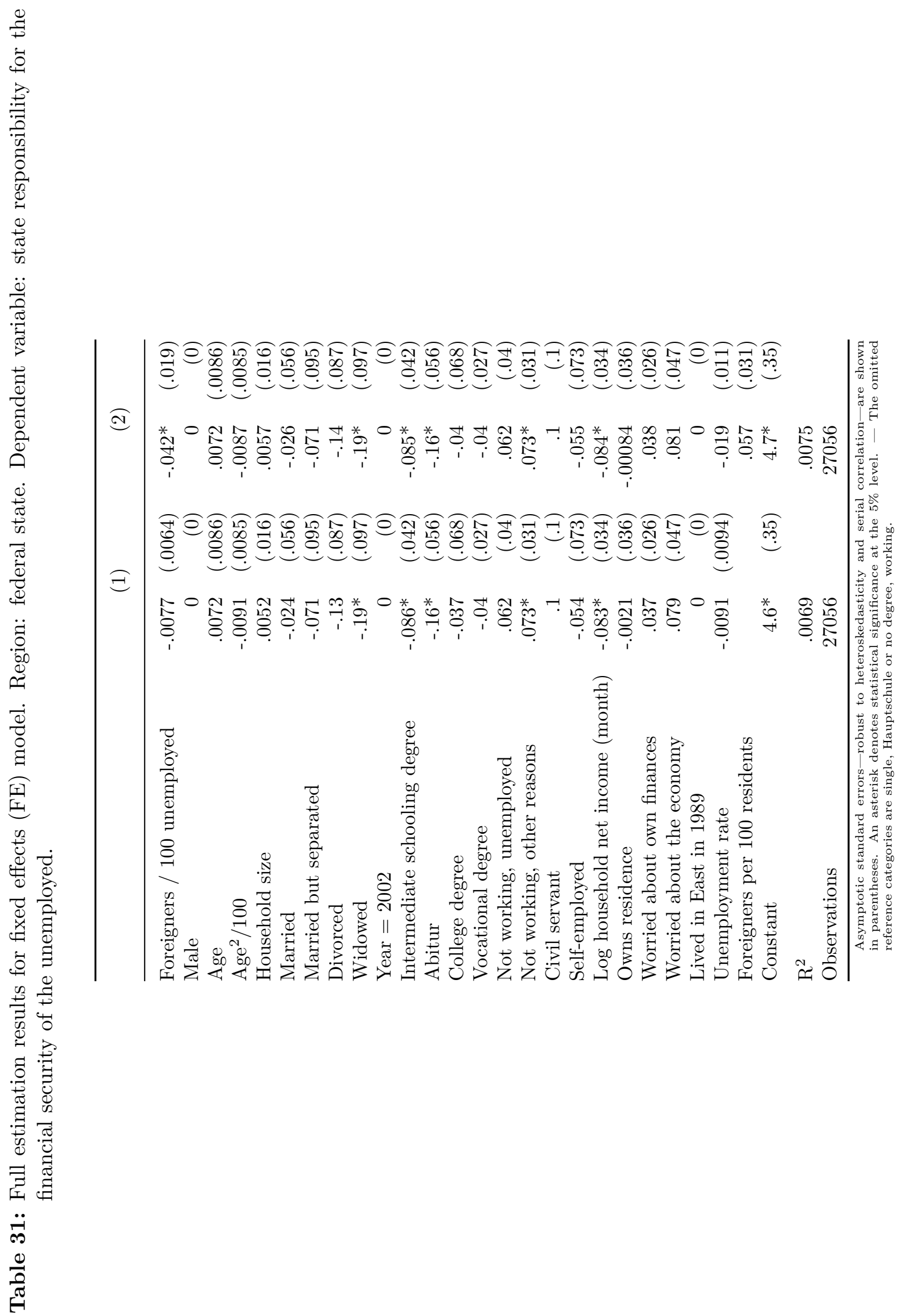

